\title{
Dynamic capabilities and environmental accounting for the circular economy in businesses
}

\author{
Sabina Scarpellini \\ Department of Accounting and Finance and CIRCE Research Institute, \\ University of Zaragoza, Zaragoza, Spain \\ Luz María Marín-Vinuesa \\ Department of Economics and Business, University of La Rioja, Logroño, Spain \\ Alfonso Aranda-Usón \\ Department of Accounting and Finance and CIRCE Research Institute, \\ University of Zaragoza, Zaragoza, Spain, and \\ Pilar Portillo-Tarragona \\ Department of Accounting and Finance, University of Zaragoza, Zaragoza, Spain
}

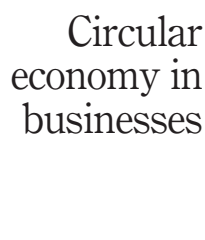

1129

Received 12 April 2019

Revised 30 July 2019 23 October 2019

Accepted 18 November 2019

\begin{abstract}
Purpose - This paper aims to define and measure the environmental capabilities that are applied when the circular economy $(\mathrm{CE})$ is introduced in businesses. Founded on the dynamic capabilities theoretical approach, the study analyzes different environmental competences that firms apply during this process. Environmental management systems, corporate social responsibility, reporting and accountability and other environmental accounting practices are studied in the same analytical framework used to study the environmental capabilities that influence the circular scope (CS) of firms. This study contributes to bridging the gap between academic research focused on environmental accounting and that investigating the introduction of the $\mathrm{CE}$ in businesses.

Design/methodology/approach - The results were obtained by using partial least squares structural equation modeling to analyze the relationship between environmental capabilities for the CE and the CS achieved by a sample of Spanish firms with more than 50 employees that expressed interest in the CE, ecodesign, eco-innovation and other environmental issues.

Findings - Based on an analysis using the dynamic capabilities theoretical approach, the results suggest a positive relationship between the CS of firms, their environmental accounting practices and their level of corporate social responsibility (CSR) and accountability. Stakeholders' pressure - which has a mediating effect on the CS of firms - is also analyzed, adding new insights to recent studies of this topic at the microlevel. The authors also explore whether the CS of businesses, which is related to the degree of their development of capabilities, influences environmental and financial performance.

Practical implications - The new insights obtained in this study can help overcome the limitations of conventional accounting approaches and incorporates a much broader scale of environmental information that can be applied to CE practices. These results also offer insights to practitioners regarding the internal measurement processes related to the $\mathrm{CE}$ and regarding CSR in particular for small and medium enterprises,
\end{abstract}

(C) Sabina Scarpellini, Luz María Marín-Vinuesa, Alfonso Aranda-Usón and Pila Portillo-Tarragona. Published by Emerald Group Publishing Limited. This article is published under the Creative Commons Attribution (CC BY 4.0) licence. Anyone may reproduce, distribute, translate and create derivative works of this article (for both commercial and non-commercial purposes), subject to full attribution to the original publication and authors. The full terms of this licence may be seen at http:// creativecommons.org/licences/by/4.0/legalcode

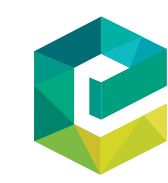

Sustainability Accounting, Management and Policy Journal Vol. 11 No. 7,2020 pp. $1129-1158$ Emerald Publishing Limited 2040-8021 DOI 10.1108/SAMPJ-04-2019-0150 
SAMPJ 11,7

because these metrics can be partially applied depending on the practices introduced in each firm. For policymakers, a better understanding of the CE's introduction into businesses will contribute to the design of policies that can enhance its deployment, for example, by providing tools that set up regional priorities depending on the CE-related practices adopted by the firms located in the territory.

Social implications - A CE involves the transformation of a linear economic model into a circular one to reduce dependence on raw materials and energy and to reduce the environmental impact of production and consumption. Understanding how to manage the specific competences that integrate capabilities applied to the $\mathrm{CE}$ will allow firms to improve their social and environmental reporting. In addition, other social implications of this study relate to improving relationships with consumers and stakeholders and to the practice of social corporate sustainability.

Originality/value - This study goes beyond previous research on the CE to extend the authors' knowledge about its adoption at the micro-level by taking a transversal approach, as its subject spans the fields of environmental accounting and the CE while addressing both in a framework of analysis. The analysis of the accounting concerns of the $\mathrm{CE}$ in businesses and the study of concerns related to endogenous environmental competences are quite original under the theoretical framework of dynamic capabilities, and this study is a first step in an incipient line of inquiry.

Keywords Stakeholders, Circular economy, Corporate finance, Environmental management accounting, Dynamic capabilities

Paper type Research paper

\section{Introduction}

In recent decades, managers' awareness of environmental issues - such as climate change, greenhouse gas emissions, waste disposal, landfill site utilization, land and water pollution, resource consumption, and the recycling of materials - has increased. In this context, the term circular economy (CE) is used by governments, researchers and businesses alike to describe an approach to sustainable development that does not constrain economic growth (Pratt et al., 2016). A CE involves the transformation of a linear economic model into a circular one to reduce dependence on raw materials and energy and to mitigate the environmental impact of production and consumption.

In summary, the main objectives of a $\mathrm{CE}$ are the reduction of the flow of materials, the achievement of energy efficiency and the continual renewal of natural and social capital through multiple phases (Yuan et al., 2006). In a CE, fewer materials are required to produce a constant level of products, either because of a reduction in the amount of resources used or because raw materials are replaced with recycled ones (Figge et al., 2017).

Several initiatives for businesses have been launched by governments in different geographic areas, In the European Union (EU), the communication "Towards a circular economy: A zero waste programme for Europe" and its annex (European Commission, 2014) laid foundations for the promotion of $\mathrm{CE}$ in the EU's member states. Among the EU's ongoing initiatives are those concerning plastics (European Commission, 2018a), energy extraction from waste (European Commission, 2017) and critical raw materials (European Commission, 2018b), in addition to those concerning renewable energy, eco-design and energy efficiency (European Commission, 2015). China led the way in enacting the Circular Economy Act (Republic of China, 2008), which was the first time that the promotion of CE was elevated to the status of law (Ghisellini et al., 2018; Mathews and Tan, 2011,2016; Wang and Li, 2006; Zhijun and Nailing, 2007). Similarly, other countries are using the principles of $\mathrm{CE}$ among businesses (Aranda-Usón et al., 2018). Even so, most companies have a long way to go before they can be considered as fully engaged in a circular business model (Witjes and Lozano, 2016). 
Research into the $\mathrm{CE}$ is also gaining ground in the academic, particularly at the macrolevel (Ghisellini et al., 2016; Kirchherr et al., 2017; Korhonen et al., 2018; Merli et al., 2018; Pomponi and Moncaster, 2017; Prieto-Sandoval et al., 2018; Urbinati et al., 2017). At the micro-level, scholars are studying the role of firms in the development of the CE (ArandaUsón et al., 2019; Katz Gerro and López Sintas, 2019; Lewandowski, 2016), but knowledge about how businesses understand and introduce the CE model is still limited, and the study of internal factors - such as resources and capabilities related to the CE in businesses - is in an early stage.

Studies conducted at the micro-level have analyzed certain resources that are being applied by firms to achieve a CE (Aranda-Usón et al., 2019; Katz Gerro and López Sintas, 2019). The financial resources applied by firms to the different activities that contribute to a CE were recently considered by Aranda-Usón et al. (2019) within the resource-based view (RBV), and different approaches to the capabilities applied to CE-related activities in businesses - founded on the theoretical framework of dynamic capabilities - were carried out by Katz Gerro and López Sintas (2019) or by Garcés-Ayerbe et al. (2019) who analyze barriers and drivers to introduce the $\mathrm{CE}$ in European businesses. Although these researchers seem to agree on the relevance of a firm's resources and capabilities to the $\mathrm{CE}$, no specific studies yet exist that explore the ways of defining and measuring environmental practices and capabilities for the CE.

If we study the capabilities that may be applicable to the CE, informal environmental management systems (EMSs), such as certification standards (ISO 14001, EMAS, ISO 50001, ISO 14006), have to be considered as important managerial competences, in addition to those indicated by Katz Gerro and López Sintas (2019). Furthermore, to extend the concept of ecoinnovation that is identified as part of a transition toward the CE (Kiefer et al., 2018), we consider that standardized processes and controls could contribute to the introduction of a CE as they do in the case of eco-innovation (Daddi et al., 2016; Park et al., 2017; PortilloTarragona et al., 2018; Rehfeld et al., 2007).

From the perspective of dynamic capabilities, reporting activities are also included in the analysis because investors' access to non-financial information is a milestone on the roadmap to resource efficiency. Environmental reporting to stakeholders and financial markets are relevant in the context of the CE (Verbeke and Buysse, 2003). Likewise, environmental accounting and environmental management accounting (EMA) need to be included in the analysis, because the circular model implies changes made in the management and accounting practices of companies to manage natural resources for cleaner production (Burritt et al., 2019).

Accounting has been identified by Burritt and Schaltegger (2001) as a tool for corporate environmental management, and EMA has been related to different environmental fields (Burritt et al., 2019). Thus, environmental accounting practices are sure to be relevant in management operational planning and decision-making processes within businesses aimed at achieving a circular model, and in particular in those applications related to such aspects of the CE as material flow and waste. Therefore, in this study we investigate the relationship between certain practices of environmental accounting and the CE-related activities that are being introduced by firms (Hong et al., 2018; Pieroni et al., 2019).

From another perspective, the influence of stakeholders in firms' adoption of the CE has been studied (Lieder and Rashid, 2016; Ranta et al., 2018; Stewart and Niero, 2018). However, to the best of our knowledge, the broad topic of stakeholder pressure and its relation with the environmental capabilities (capabilities applied to the environmental activities of firms) 
SAMPJ

11,7

1132

that firms have to manage to introduce the $\mathrm{CE}$ in their processes, particularly if a circular business model is adopted, remains open.

On these bases, the main objective of this study is to define and measure in a broader framework the environmental capabilities that firms apply to introduce the CE. This study goes beyond previous research to extend our knowledge of the adoption of the $\mathrm{CE}$ at the micro-level by using a transversal approach, as the topic bridges the fields of environmental accounting and the $\mathrm{CE}$ while addressing both theoretical and methodological issues.

To this end, a model of the cause-and-effect relationship between firms' circular scope (CS) and their level of environmental capabilities and stakeholder pressure has been designed by using partial least squares structural equation modeling (PLS-SEM), which was tested in a sample of Spanish companies.

The remainder of the article is structured as follows. Following a review of the literature in the background (Section 2), the methodology and the sample description are included (Section 3). In Section 4, the main results and the discussion are summarized within the dynamic capabilities framework, while conclusions are presented in Section 5.

\section{Background}

\subsection{Circular scope and environmental capabilities}

The CE is becoming a topic of increasing interest among scholars in the social sciences because it is a relevant instrument in the search for solutions to problems regarding resource efficiency and the sustainable consumption of materials across all stages of the value chain (Yuan et al., 2006). Researchers also show a burgeoning interest in the introduction and measurement of the CE in firms (Aranda-Usón et al., 2019; Lewandowski, 2016; Pauliuk, 2018), although the adoption of this model by private firms remains poorly understood (Stewart and Niero, 2018).

To date, the literature has mainly focused on factors that affect the commitment of private firms to the CE, on existing barriers and incentives (Ormazabal et al., 2016, 2018), and on the adoption of the circular business model (Bocken et al., 2014, 2016; Mentink, 2014; Witjes and Lozano, 2016). In summary, the circular business model aims to reduce companies' dependence on raw materials and to promote the transition from fossil fuels to renewables and the adoption of sustainable production in the value chain (Linder and Williander, 2017; Zamfir et al., 2017).

To measure the introduction of the circular business model and the $\mathrm{CE}$ at the micro-level, particular indicators have been applied to products (Linder et al., 2017; De los Rios and Charnley, 2017; Di Maio and Rem, 2015) and consumers (Borrello et al., 2017). However, only a few studies have looked at measuring the level of CE achieved by a company as a whole (Aranda-Usón et al., 2019; Pauliuk, 2018), and there is still no consensus on how to measure the different $\mathrm{CE}$ principles introduced by firms. In particular, the definition and measurement of the capabilities that firms are required to have to introduce the $\mathrm{CE}$ remain under investigation.

Resources and capabilities have been demonstrated to be relevant to success in environmental strategy within the theoretical framework of an RBV of the firm (Barney, 1991, 2001) and its extension to dynamic capabilities (Teece et al., 1997). In recent years, the dynamic capabilities-based perspective has provided a theoretical basis for analyzing the competitive advantage resulting from a firm's environmental improvements (Aragón-Correa and Rubio-López, 2007; Boiral, 2007; Essid and Berland, 2018; Iñigo and Albareda, 2016; Kabongo and Boiral, 2017; Katz Gerro and López Sintas, 2019). Under the dynamic capabilities framework, the competitive advantage lies in the firm's capacity to integrate, 
build and reconfigure business competences to better adapt to the changing business environment (Eisenhardt and Martin, 2000; Teece et al., 1997; Zollo and Winter, 2003).

Zollo and Winter (2003) define dynamic capability as the learned and stable pattern of collective activity through which an organization systematically generates and modifies its operating routines in the pursuit of improved effectiveness. Teece (2007) points out that in the dynamic capabilities framework, success in management innovation can be achieved by a firm in creating, extending and modifying its resource base. A number of studies conducted within the dynamic capabilities perspective have analyzed the antecedent organizational routines by which managers alter their deployment of resources to generate new value-creation strategies (Ambrosini et al., 2009; Eisenhardt and Martin, 2000; Scott, 2013; Teece, 2007; Wu et al., 2012). Thus, from the perspective of a $\mathrm{CE}$, dynamic capabilities are considered well suited to the study of circular patterns in firms (Katz Gerro and López Sintas, 2019), because this theoretical approach can capture proactive environmental strategies related to the sustainability of competitive advantage in dynamic environments.

According to Katz Gerro and López Sintas (2019), interdependence among CE activities should produce better environmental and financial performance. The implementation of the 3R's (reduction, reuse and recycling) within firms is also understood as a dynamic capability that includes interrelated CE practices to achieve a common goal (Zeng et al., 2017). Consequently, a firm's development of CE-related activities must follow a certain trajectory of competence and activity development.

In addition, some authors highlight the importance of developing dynamic capabilities to support proactive environmental strategies through adopting informal EMSs (AragónCorrea and Sharma, 2003; Russo, 2009; Zhu et al., 2013). In fact, path-dependent learning, such as that exemplified in ISO 14001 and related EMSs, comprises an important aspect of the dynamic capabilities (Zhu et al., 2013) that are deployed when environmental management tools are adopted.

Despite the fact that EMSs vary in their ability to mitigate environmental impacts, they can be considered as complementary competencies that may support the CE-related activities of firms. Scholars have demonstrated that EMSs improve environmental performance (Aravind and Christmann, 2011; Boiral et al., 2018), and they have been highlighted as potential conduits for the development of firms' environmental capabilities for eco-innovation (Amores-Salvadó et al., 2015). However, the impact of EMSs on the CE in businesses has not, to date, been empirically investigated. Thus, following this analysis of the literature, the first research question proposed in this study is as follows:

\section{RQ1. Is the adoption of EMSs related to the CS of firms?}

In summary, in this study, the CS is considered to be the level of adoption of CE-related practices by businesses and is used to define the different activities (their number and range) that firms have introduced to close the loops in terms of a CE. In a CE framework, firms are currently expected to integrate environmental responsibility at all levels of their operations, find sustainable solutions for reducing the consumption of natural resources, manage environmental risks ensuring reduction in waste, pollution, and emissions and maximize the efficiency and productivity of all assets and resources, including improvements in the management of water, energy and materials (Katsoulakos and Katsoulacos, 2007). The extent to which these practices are introduced in businesses - which in this study is briefly defined as CS - can lead to different levels of loops closure in terms of a CE, and its measurement in still under investigation. 
SAMPJ

11,7

1134

\subsection{Environmental accounting and management for a circular economy}

The $\mathrm{CE}$ has emerged as a solution to the wide-ranging challenges presented by economic growth and sustainability (Franco, 2017), and it implies that firms must define and measure the investments they make and the activities they carry out to close loops. Thus, when a circular business model is adopted, environmental accounting practices become more relevant within firms.

There is a variety of concepts involved in environmental accounting. Tanc and Gokoglan (2015) offer an exhaustive definition of this concept and its genesis in the literature. They discuss it as a combination of accounting practices used in studying mutual relations between accountants and ecology, awareness of environmental cost information and settled environmental costs distribution to the appropriate products and processes.

Although some aspects of the adoption of environmental accounting processes by companies have been studied (Wilmshurst and Frost, 2001), little is known thus far about how information relating to the $\mathrm{CE}$ principles introduced by businesses should be accounted, gathered, analyzed and internally reported. The paradigm shifts from providing financial information to reporting social and environmental concerns, that is a missing link in our knowledge of sustainable practices and strategy development (Collins et al., 2011), particularly when circular business models are adopted by firms.

The accounting data inherent to the CE that could potentially be separated and reported may arise from environmental issues depending on the nature of the business, such as tangible and intangible assets related to the application of environmental laws and regulations. Investments and expenses related to participation in carbon trading schemes; assets and provisions related to soil, groundwater or air pollution, the use of hazardous substances or the disposal of waste; and fines or penalties incurred are also issues that have to be reported. In facts, financial flows related to climate change risks and potential flood risks are relevant data for firms in a circular model. In particular, the decision-making process about investments to improve the environmental performance is influenced by environmental pressures, the increasing energy costs or other activities, such as estimating impacts on the risk management policy of the company or determining appropriate financial provisions for liabilities, pollution, environmental contamination and the restoration of wildlife habitats, are becoming more relevant.

In such a context, we can assume that a CE-related accountancy might involve, principally, a reappraisal of the identification and measurement of the relevant costs of processes and products. Such accounting may include life cycle management (Qian et al., 2011), environmental cost accounting, environmental liabilities, environmental investment appraisal, life cycle assessment (LCA) and life cycle costing. In particular, the "3R" principles of a CE (Jawahir and Bradley, 2016; Liu and Bai, 2014) have been combined with material flow cost accounting (MFCA) as a method of EMA (Zhou et al., 2017) that has been introduced by firms for eco-innovation.

Albelda (2011) has demonstrated that management accounting is a facilitator of environmental management, and there is no doubt that the application of specific costing methods and the calculation of the value of flows will provide valuable information for environmental management and for the decision-making process regarding circular business models (Yang et al., 2019). There is, however, little evidence to demonstrate the role of EMA in improving sustainability in all types of businesses and, in particular, in addressing the CE-related issues. To the best of our knowledge, no specific studies analyze the level to which companies have introduced EMA in a CE framework to, for instance, post entries related to environmental activities and investments and specific information about sustainability in a circular model. 
In a wider context, the managerial environmental capabilities related to top managers' environmental commitment have been analyzed for eco-innovation (Chang and Chen, 2013; Del Río et al., 2012, 2016). Thus, a joint environmental management competence, which includes the availability of human resources for the CE and EMA, needs to be explored. Therefore, a second research question is considered in this study:

RQ2. Are environmental accounting and management capabilities related to the circular economic scope of firms?

\subsection{Reporting and accountability in a circular model}

Reporting practices that include both financial and non-financial key environmental performance indicators are expected to be relevant to redirecting businesses toward a CE. At present, the level of information on environmental matters provided by firms is a topic of interest in the literature on sustainability. Research has focused on analyzing the inclusion of environmental data in annual accounts by using social and environmental standards (Mathews, 2008), disclosure practices and accountability in green sectors (Burritt and Schaltegger, 2010; Llena et al., 2007; Walton, 2000) and cleaner production (Marco-Fondevila et al., 2018). In this context, the reporting of environmental information and its quality are interesting topics to the $\mathrm{CE}$ research community, although very few authors have addressed these issues (Stewart and Niero, 2018).

Yearly, an increasing number of large companies release corporate social responsibility (CSR) reports that are provided to their external stakeholders. In particular, regarding companies' approaches to the CE, CSR reports have been used by scholars as a data source with which to investigate CE-related activities (Sihvonen and Partanen, 2017; Stewart and Niero, 2018). In CE studies, CSR has generally been framed in terms of the "triple bottom line" of sustainability (Merli et al., 2018). While studies focusing on eco-innovation have demonstrated the relation between eco-innovative activities and environmental disclosure policies (Correa et al., 2013; Marco et al., 2019; Ruiz-Romero et al., 2013), the relation between CSR and the introduction of a CE in businesses has not been specifically addressed.

Departing from these premises, this study aims to explore the link between the CS achieved by firms and their CSR practices, because this investigation might yield different results from those found in studies of companies carrying out eco-innovation. Therefore, the following research question is considered:

\section{RQ3. Are the levels of CSR and accountability of firms related to their CS?}

\subsection{Circular economy and stakeholders}

There is a general understanding that both $\mathrm{CE}$ and sustainable business practices require a systematic perspective on the role of businesses in the wider system of stakeholders and the environment (Murray et al., 2017; Pauliuk, 2018). The environmental behavior of a company in a CE context is influenced by not only internal factors but also its external context (Liu and Bai, 2014). Research has demonstrated that stakeholder pressure positively affects environmental proactivity and the adoption of a circular business model (Witjes and Lozano, 2016) to generate value according to the firms' internal activities (Urbinati et al., 2017). Thus, to define a comprehensive set of CE-related indicators, the needs of all stakeholders should be satisfied (Banaite and Tamosiuniene, 2016).

The role of stakeholders is an issue that intersects with the introduction of a $\mathrm{CE}$ at the micro-level, owing to benefits such as cost savings, investments in innovation, improved 
SAMPJ

11,7

customer relationships and the resilience of organizations (Pauliuk, 2018). However, to the best of our knowledge, no specific empirical studies have yet focused on stakeholder pressure and the CS of businesses, and one of the objectives of this study is to begin to fill this gap. To that end, the fourth research question is proposed:

\section{RQ4. Is the level of stakeholder' pressure related to the CS of firms?}

To answer these four research questions, the methodology described in the following section was designed.

\section{Methodology and sample description}

\subsection{Sample and data collection}

To achieve the objectives of this research study, we empirically analyzed surveys obtained through the active cooperation of sample Spanish firms with more than 50 employees. Size was considered a relevant characteristic of firms in the transition from a linear model to a circular one because it is a factor that facilitates eco-innovative processes (Aboelmaged, 2018; Triguero et al., 2015; Wagner, 2007; Zhang and Walton, 2017).

The population from which the sample of firms was selected was defined in the framework of an R\&D project[1] and through a specific campaign promoting eco-innovation, eco-design, and the $\mathrm{CE}$ in the Northeast Spanish regions of Aragon, Catalonia, Navarre, and the Basque Country, that is an area with high eco-innovation rates which offers earlier results about ecoinnovative firms at regional level (Scarpellini et al., 2019). Aiming at focusing the research on cases where proactive environmental strategy can be considered a truly competitive advantage, in line with the dynamic capabilities theoretical framework, the sample was shortened to those companies operating in sectors with the greatest potential for eco-innovation, eco-design or the CE. Thus, surveyed firms were selected if they were operating in industries related to the technologies referred to in the documents as "BREFs" of "Best Available Techniques"[2]. These industries include industrial transport and logistics; waste; the extractive industry; the manufacturing industry; electricity, gas, steam and air conditioning supply; water supply; sewerage; waste management; transport; and storage. Although this selection criterion may exclude some companies that are adopting a circular business model, it is believed that, following Ding (2014), this criterion selects the vast majority of firms that are eco-innovating. Moreover, we consider that the majority of firms that are introducing CE-related activities are included in these industries, in line with Aranda-Usón et al. (2019) who consider these sectors provide the technological conditions for the introduction of the $\mathrm{CE}$ at micro-level. The objective was to count on companies with proven proactivity in these practices and investments. And the eco-innovative nature of firms and theirs interest on the $\mathrm{CE}$ were determined through their active participation in the collaborative project.

The sample was obtained through refining a list of 2,232 companies elaborated from the $\mathrm{SABI}$ database[3] that provides main economic and financial figures of Iberian companies. In 2015, 996 questionnaires were e-mailed to these companies with detailed contact information. Finally, 110 surveys were obtained, and 87 of them were considered complete observations for this study, representing a final sample of 8.8 per cent. The main data collection instrument used was a questionnaire (Figure A1) that was e-mailed to the firms' managers who answered through an on-line platform to collect the primary data. It should be highlighted that the main objective of this study required the collection of internal data from potential CE-interested companies that are carrying out eco-innovation, eco-design or related investments to assess the internal resources of businesses.

The focal respondents were managers in charge of these investments or, failing that, the firms' managers because their linkage with eco-innovation implementation has been 
demonstrated by Marín-Vinuesa et al. (2018) and by Rivera-Torres et al. (2015) who empirically demonstrate the impact of the environmental concerns on internal organization. Thus, managers were considered as adequate to collect information about the investments of companies and their perception because of their knowledge, experience and expertise (Oduro and Haylemariam, 2019).

The companies that filled out the questionnaire were identified by their value added tax numbers to obtain financial data. Consequently, the research included qualitative data (obtained from managers) and quantitative data (those collected from the SABI database). The collaboration with identified firms for the empirical analysis means a smaller number of valid observations, but the identification of the companies in the sample allows us to integrate the economic-financial data of the companies with their position regarding the $\mathrm{CE}$ and the specific resources allocated.

\subsection{Measurement and variables}

To answer to the research questions formulated in this study, three groups of CE-related activities and competencies are analyzed: EMS, environmental capabilities and accounting (EA), CSR and accountability. In addition, the financial performance of the companies and stakeholder pressure was measured as well.

The variables were selected or designed to measure the relationship between the CS achieved by firms and its relationship with the above-described environmental capabilities of the firms. To select these variables, methods used in other studies were taken as a starting point, and specific variables were elaborated for this study. Tables I, II and III provide the scale items of the constructs obtained for the analysis.

As already observed in the literature review, methods for designing specific CE indicators are being developed, but a gap remains regarding $\mathrm{CE}$ indicators at the organizational level (Pauliuk, 2018). A dashboard of quantitative indicators for the implementation of a CE in organizations has been proposed by Pauliuk (2018) through MFCA and LCA, which have been identified by other authors, too, as methods for assessing environmental strategy in organizations (Daddi et al., 2017; Haas et al., 2015; Huysman et al., 2017; Pratt et al., 2016). In a similar line of research, Zhou et al. (2017) have applied a composite index based on MFCA to the analysis of CE performance in firms. However, the application of these proposals is limited to businesses that have introduced these tools and that operate mainly in the manufacturing and industrial sectors. Thus, this study applies the set of indicators recently proposed by Aranda-Usón et al. (2019) for measuring the CS of a firm at an organizational level (Table I).

The construct called "environmental capabilities for the CE," to measure the firm competences deployed for CE-related activities, includes qualitative data about environmental reporting derived from managers' responses about their standards and procedures. Taking into account the capabilities that may be applicable to the $\mathrm{CE}$, this construct measures formal and informal EMSs through the certification standards that the firms hold, such as ISO 14001, EMAS, ISO 50001 and ISO 14006 (Table II). These responses include the type and volume of environmental information reported about the adoption of the EMS.

From another perspective, certain environmental items may require special treatment, owing to their negative impact with regard to the introduction of a circular business model. To this end, the advantages of the EMA system pointed out by Cullen and Whelan (2006) are considered, such as the identification, classification and allocation of costs for the reduction of the negative impact and decision-making (Adams, 2002; Bartolomeo et al., 2000; Gibson and Martin, 2004). This study also proposes a general variable for measuring the extent to

\section{Circular economy in businesses}

1137 


\section{SAMPJ \\ 11,7}

Environmental activities related to the $\mathrm{CE}$ : CS

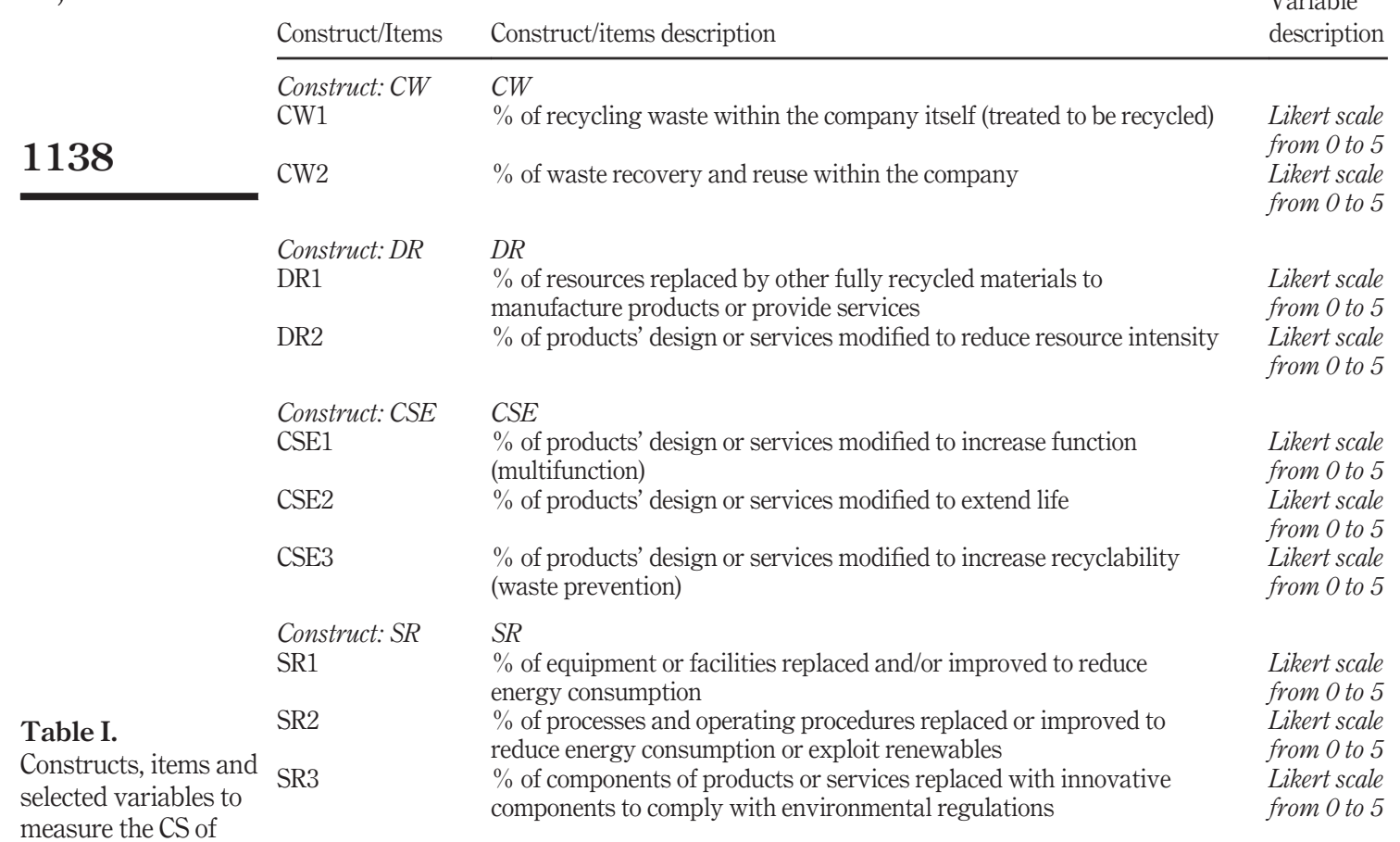
businesses

Source: Aranda-Usón et al. (2019)

which companies post entries related to environmental activities and investments and specific information about sustainability. These variables were developed in line with those applied by Marco et al. (2019) to the eco-innovation carried out by these firms. The human resources available for environmental management are also considered, and they are measured in accordance with the procedures used by Scarpellini et al. (2017).

Finally, in a CE model in which environmental issues have a material impact, specific disclosures may be necessary (Table II). A third variable integrates the construct to measure the dissemination of good corporate governance rules, because this assures the firm's capability of reconfiguring internal and external competences to address the new environments required by the $\mathrm{CE}$. Thus, the qualitative data regarding managers' perceptions of environmental disclosure were gathered to measure the relevance and importance of environmental proactivity (Luque-Vílchez et al., 2019) and of environmental reporting to managers, based on their policies regarding transparency and accountability (Marco et al., 2019).

In two separate constructs, other variables were introduced to measure managers' perceptions regarding stakeholders' pressure, and the financial performance of firms was measured using a construct from three indicators (Hamann et al., 2013): return on equity, return on sales and return on assets (Table III). 
Environmental capabilities for the $\mathrm{CE}$

\begin{tabular}{ll} 
Construct/Items & Construct/Items description \\
\hline $\begin{array}{l}\text { Construct: } \\
\text { EMS }\end{array}$ & $\begin{array}{l}\text { EMS } \\
\text { Level to which the company implements the ISO } 14001 \text { standards }\end{array}$ \\
EMS2 & Level to which the company implements the EMAS standards \\
EMS3 & Level to which the company implements the ISO 50000 standards \\
EMS4 & Level to which the company implements the ISO 14006 standards
\end{tabular}

Construct: EA EA

EA1 Level to which the company posts entries related to environmental activities and investments and specific information about sustainability

EA2 Number of employees in the environmental management department or similar

EA3

Level to which the company applies and disseminates its good corporate governance rules

Construct: CSR CSR

CSR1 Level to which the company adheres to the CSR model compared to other companies in the sector

CSR2

Level to which the company voluntarily reports on its activity related to

CSR3 sustainability in open access platforms (web, reports and press)

Level to which the company provide specific sustainability reports of environmental impacts addressed to stakeholders

CSR4
Variable

description

Likert scale

from 0 to 5

Likert scale

from 0 to 5

Likert scale

from 0 to 5

Likert scale

from 0 to 5

Likert scale

from 0 to 5

Likert scale

from 0 to 5

Likert scale

from 0 to 5

Likert scale

from 0 to 5

Likert scale

from 0 to 5

Likert scale

from 0 to 5

Likert scale

from 0 to 5
Circular
economy in
businesses

1139

Table II.

Constructs, items and selected variables to

measure

environmental capabilities for the

CE

\begin{tabular}{ll}
\hline $\begin{array}{l}\text { Construct: } \\
\text { ST }\end{array}$ & ST \\
\hline ST1 & $\begin{array}{l}\text { Degree to which th } \\
\text { comply with regul } \\
\text { Level of social pre } \\
\text { impact }\end{array}$ \\
ST2 & $\begin{array}{l}\text { FP } \\
\text { Variable }\end{array}$ \\
FP1 & Return on equity \\
FP2 & Return on sales \\
FP3 & Return on assets
\end{tabular}

Variable FP

S1 Number of employees

S2 Total revenues (thousand euros)

S3 Total assets (thousand euros)
Variable description

Likert scale from 0 to 5

Likert scale from 0 to 5

$\operatorname{Min}=-5.508 ;$ Max $=$

0.779

$\operatorname{Min}=-0.751 ;$ Max $=$

5.000

$\operatorname{Min}=-1.502 ; \operatorname{Max}=$ 0.491

$\operatorname{Min}=50 ;$ Max $=$

14,106

$\operatorname{Min}=3,952.41$;

Max $=8,597,300$

$\operatorname{Min}=1,362.61$;

Max $=48,300,000$
Table III.

Constructs, items and selected variables to measure stakeholder pressure and the financial performance of the firms contained in the sample 
SAMPJ

11,7

1140

On the other hand, the variables, organizational size and industry sector, were included as control variables in the statistical analysis. The organizational size (S) was measured using a construct from three indicators (Table III): number of employees, total revenues and total assets (Aboelmaged, 2018; Triguero et al., 2015; Wagner, 2007; Zhang and Walton, 2017). The industry sector, to which the firm belongs, was measured by using two dichotomous variables in line with Aranda-Usón et al. (2019) and Ding (2014): manufacturing industry (MI) variable that takes the value 1 if the firm is from the manufacturing and 0 otherwise; and transport and storage industry (TI) variable that takes the value 1 if the firm is from this industry and 0 otherwise. In this way, we examine outcome considering three different sectors, the manufacturing, the transport and storage and the other industries. We select these variables by considering the sample distribution regarding industry sector; the largest percentage of the firms in the sample (59.77 per cent) was made up of firms that belong to the manufacturing industry followed by those industries involved in transport and storage (24.14 per cent) and other industries (16.1 per cent), which include power, gas, steam and airconditioning supply, water-supply, drainage, waste management and decontamination and mining.

\subsection{Statistical analysis}

Given the objectives of this study, we used SEM based on the PLS approach for measurement, validation and testing of the structural model. We used SmartPLS version 3.0 (Ringle et al., 2015), because the PLS approach enabled us to estimate a complex model with many latent variables, indicator variables and structural paths. The variance-based PLS method is preferable to the covariance-based alternative when the construct modeling is established as a composite model of multiple indicators and multiple causes (MIMIC), and the conceptualization of the measurement model is reflective (Sarstedt et al., 2016). The application of a MIMIC approach in covariancebased structural equation modeling could place constraints on the model that would contradict the theoretical assumptions. PLS analysis was deemed suitable for this study because one segment of the study is measured by using a single item (Hair et al., 2019).

This study applies the ten times rule proposed by Hair et al. (2011) for determining appropriate sample size when using PLS. The rule of thumb is that the sample size should be greater than ten times the maximum number of inner or outer links pointing at any latent variable in the model (Goodhue et al., 2018). In our proposed model, the highest number of paths leading to a dependent variable is three, while the number of indicators on the latent variable is five. Thus, according to this rule, the minimum required sample size would be 50 . The 87 responses in the data set are thus sufficient to perform PLS properly.

To determine whether or not common method bias threatens the interpretation of our results, two criteria were examined (Podsakoff and Organ, 1986). First, Harman's one-factor test was used; when all indicators are entered into a principal components factor analysis, no single factor accounts for the threshold of 50 per cent variance, indicating no substantial common method bias. Second, when the matrix of bivariate correlations between constructs was examined, the correlations were not high $(r<0.9)$, meaning the criterion was fulfilled (Bagozzi and Yi, 1988). These results suggest that common method bias is not a serious threat in our study.

The empirical analysis was carried out in two phases. In the first phase, the measurement model was estimated. In the second phase, the structural relationships outlined in the structural model were assessed. 


\section{Main results and discussion}

\subsection{Measurement model}

The measures from the data set were tested by assessing the unidimensionality and reliability of the multi-item constructs. First, an exploratory factor analysis (EFA) was performed by using principal components analysis, followed by varimax rotation for factor extraction. To test the appropriateness of the data for the EFA, the Kaiser-Meyer-Olkin (KMO) measure of sampling adequacy and Bartlett's sphericity test were used. The results of the EFA showed that the multiitems constructs - environmental management systems (EMS), environmental capabilities and accounting (EA), CSR and accountability (CSR), waste recovery (CW), dematerialization and recycled materials (DR), circular eco-design (CSE), resource saving and efficiency (SR), stakeholders (ST), financial performance (FP), and size organizational (S) - were all formed by a single factor with a high explained variance: $\mathrm{EMS}=48.8$ per cent $(\mathrm{KMO}=0.68), \mathrm{EA}=51.1$ per cent $(\mathrm{KMO}=0.56), \mathrm{CSR}=60.5$ per cent $(\mathrm{KMO}=0.77), \mathrm{CW}=81.5$ per cent $(\mathrm{KMO}=0.5), \mathrm{DR}=$ $57.6(\mathrm{KMO}=0.5), \mathrm{CSE}=61.4$ per cent $(\mathrm{KMO}=0.56), \mathrm{SR}=57.3$ per cent $(\mathrm{KMO}=0.5), \mathrm{ST}=67.9$ per cent $(\mathrm{KMO}=0.5), \mathrm{FP}=59$ per cent $(\mathrm{KMO}=0.55), \mathrm{S}=79$ per cent $(\mathrm{KMO}=0.53)$. For all scales, the KMO index provided good results, and Bartlett's sphericity tests reflected a significance level of less than 0.001. These results show the appropriateness of the EFA analysis performed.

Next, we verified the reliability and validity of the measurement model. Convergent validity was assessed through the average variance extracted (AVE), composite reliability (CR) and variables' standardized loadings (Table IV). All constructs had an AVE that exceeded the recommended value of 0.5 (Bagozzi and Yi, 1988). This means that over 50 per cent of the construct variance was because of its indicators. The consistency of the indicators that formed each factor was also ensured by examining the CR index. In all cases, this index achieved very high values - all higher than 0.7 and, in some cases, near 0.8 or higher. Moreover, for all variables, standardized outer loadings were close to 0.7 or higher and were thus found to be significant. These results confirm the adequate convergent validity of the model for the selected indicators.

To verify the discriminant validity of the model, we confirmed that the square root of the AVE of each construct was larger than the correlations among constructs (Table V). Later, the matrix of loadings and cross loadings was examined to confirm that the model loadings were larger than the cross loadings (Table VI). However, some cross loadings attain values higher than 0.4 for the other constructs (CSR1/ST: 0.41; SR3/DR: 0.77; DR2/CSE: 0.54; and DR1/SR: 0.66).

To further explore this issue, the heterotrait-monotrait (HTMT) criterion was examined to confirm that all values of correlations between the constructs are below 0.85 (Table V). The HTMT ratio of correlations has been established as a criterion superior to other ones (the Fornell-Larcker criterion and the examination of cross loadings) for measuring the discriminant validity (Henseler et al., 2016). Given that the HTMT ratio criterion was met in our analysis and that the standardized outer loadings were higher than 0.7 in all cases, we conclude that the measurement model showed adequate convergent validity and discriminant validity.

Despite the fact that the discriminant validity criterion was met, the information provided by the respondents about the resources/products managed for the dematerialization and the use of recycled materials.

We applied the second-order construct type II or higher component model (HCM) type reflective-formative measurement model (Ringle et al., 2015). To analyze the relationships between the first-order and second-order constructs, the following steps were carried out. First, an EFA analysis was performed using principal components analysis; both environmental capabilities for the $\mathrm{CE}$ (ECA) and CS were found to be higher-order constructs (HCMs), with second factors represented by three (in the case of ECA) and four (in the case of CS) first-order factors. Second, we analyzed the validity of the HCMs with 


\begin{tabular}{|c|c|c|c|c|}
\hline & & & & \\
\hline $\begin{array}{l}\text { SAIVIPJ } \\
117\end{array}$ & Construct/Items & Outer loadings & AVE & $\mathrm{CR}$ \\
\hline & $E M S$ & & 0.491 & 0.762 \\
\hline & EMS1 & 0.666 & & \\
\hline & EMS2 & 0.671 & & \\
\hline & EMS3 & 0.737 & & \\
\hline 1142 & EMS4 & 0.703 & & \\
\hline & $E A$ & & 0.511 & 0.755 \\
\hline & EA1 & 0.742 & & \\
\hline & $\begin{array}{l}\text { EA2 } \\
\text { EA3 }\end{array}$ & $\begin{array}{l}0.801 \\
0.637\end{array}$ & & \\
\hline & & & & \\
\hline & CSR & & 0.604 & 0.859 \\
\hline & CSR1 & 0.688 & & \\
\hline & CSR2 & 0.830 & & \\
\hline & CSR3 & 0.843 & & \\
\hline & CSR4 & 0.740 & & \\
\hline & $C W$ & & 0.701 & 0.822 \\
\hline & CW1 & 0.926 & & \\
\hline & CW2 & 0.737 & & \\
\hline & $D R$ & & 0.576 & 0.731 \\
\hline & DR1 & 0.769 & & \\
\hline & DR2 & 0.749 & & \\
\hline & CSE & & 0.607 & 0.820 \\
\hline & CSE1 & 0.881 & & \\
\hline & CSE2 & 0.799 & & \\
\hline & CSE3 & 0.638 & & \\
\hline & $S R$ & & 0.572 & 0.798 \\
\hline & SR1 & 0.739 & & \\
\hline & SR2 & 0.857 & & \\
\hline & SR3 & 0.660 & & \\
\hline & $S T$ & & 0.679 & 0.809 \\
\hline & ST1 & 0.826 & & \\
\hline & ST2 & 0.822 & & \\
\hline & $F P$ & & 0.573 & 0.801 \\
\hline & FP1 & 0.769 & & \\
\hline & FP2 & 0.765 & & \\
\hline & FP3 & 0.737 & & \\
\hline Table IV. & $S$ & & 0.676 & 0.858 \\
\hline Validity and & S1 & 0.874 & & \\
\hline reliability for & S2 & 0.960 & & \\
\hline constructs & S3 & 0.625 & & \\
\hline
\end{tabular}

PLS-SEM to demonstrate that the relationship between each second-order factor, and its first-order factors was one of statistical significance (Hair et al., 2011). Next, a bootstrapping procedure with 5,000 iterations was performed to examine the statistical significance of the relationships between the constructs. Table VII shows the statistical significance of weights $(p<0.01$ and $p<0.05)$ of the first-order constructs on the specified second-order constructs. Subsequently, we confirmed the environmental capabilities for the CE (ECA) as an HCM 


\begin{tabular}{lllllllllll}
\hline Construct & CSR & EA & EMS & CW & DR & CSE & SR & ST & FP & S \\
\hline CSR & 0.777 & 0.661 & 0.471 & 0.222 & 0.21 & 0.199 & 0.223 & 0.68 & 0.314 & 0.273 \\
EA & $0.405^{* * * *}$ & 0.714 & 0.563 & 0.193 & 0.357 & 0.294 & 0.351 & 0.542 & 0.556 & 0.798 \\
EMS & $0.325^{* * * *}$ & $0.31^{* * *}$ & 0.706 & 0.173 & 0.152 & 0.199 & 0.292 & 0.391 & 0.398 & 0.672 \\
CW & $0.156 \mathrm{~ns}$ & $0.014 \mathrm{~ns}$ & $0.021 \mathrm{~ns}$ & 0.837 & 0.247 & 0.179 & 0.277 & 0.26 & 0.231 & 0.123 \\
DR & $0.134 \mathrm{~ns}$ & $0.138 \mathrm{~ns}$ & $0.117 \mathrm{~ns}$ & $0.164 \mathrm{~ns}$ & 0.759 & 0.761 & 0.797 & 0.374 & 0.225 & 0.416 \\
CSE & $0.098 \mathrm{~ns}$ & $0.003 \mathrm{~ns}$ & $0.031 \mathrm{~ns}$ & $0.021 \mathrm{~ns}$ & $0.381^{* * *}$ & 0.779 & 0.271 & 0.19 & 0.13 & 0.141 \\
SR & $0.140 \mathrm{~ns}$ & $0.135 \mathrm{~ns}$ & $0.076 \mathrm{~ns}$ & $0.203 \mathrm{~ns}$ & $0.599^{* *}$ & $0.285 \mathrm{~ns}$ & 0.756 & 0.284 & 0.277 & 0.408 \\
ST & $0.435^{* * * *}$ & $0.254^{* *}$ & $0.215^{* *}$ & $0.153 \mathrm{~ns}$ & $0.206 \mathrm{~ns}$ & $0.06 \mathrm{~ns}$ & $0.138 \mathrm{~ns}$ & 0.824 & 0.359 & 0.474 \\
FP & $0.223^{* *}$ & $0.363^{* * *}$ & $0.243^{* * *}$ & $0.046 \mathrm{~ns}$ & $0.081 \mathrm{~ns}$ & $0.017 \mathrm{~ns}$ & $0.196 \mathrm{~ns}$ & $0.224 * *$ & 0.757 & 0.458 \\
S & $0.203^{* * * *}$ & $0.507^{* * *}$ & $0.452^{* * * *}$ & $-0.079 \mathrm{~ns}$ & $0.219^{* * *}$ & $-0.092 \mathrm{~ns}$ & $0.301^{* *}$ & $0.292 \mathrm{~ns}$ & $0.336 * *$ & 0.822
\end{tabular}

Notes: Values below the diagonal are correlations between factors $(* * * p<0.01 ; * * p<0.05$; ns $=$ not significant). Values above the diagonal: ratio HTMT 0.85 criterion; values in italics are the square root of the AVE of each construct

Table V. Discriminant validity

\begin{tabular}{|c|c|c|c|c|c|c|c|c|c|c|}
\hline Construct & EMS & EA & CSR & CW & DR & CSE & SR & ST & $\mathrm{FP}$ & $\mathrm{S}$ \\
\hline EMS1 & 0.666 & 0.198 & 0.137 & 0.064 & 0.093 & 0.007 & -0.092 & 0.097 & 0.049 & 0.121 \\
\hline EMS2 & 0.671 & 0.164 & 0.249 & 0.002 & 0.103 & 0.049 & 0.129 & 0.185 & 0.161 & 0.241 \\
\hline EMS3 & 0.737 & 0.262 & 0.218 & 0.069 & 0.019 & -0.063 & 0.004 & 0.114 & 0.135 & 0.395 \\
\hline EMS4 & 0.703 & 0.205 & 0.251 & -0.067 & 0.107 & -0.063 & 0.133 & 0.173 & 0.242 & 0.398 \\
\hline EA1 & 0.266 & 0.742 & 0.238 & -0.034 & 0.254 & 0.117 & 0.15 & 0.258 & 0.169 & 0.387 \\
\hline EA2 & 0.293 & 0.801 & 0.302 & -0.014 & 0.056 & -0.149 & 0.088 & 0.244 & 0.362 & 0.362 \\
\hline EA3 & 0.079 & 0.637 & 0.340 & 0.023 & -0.028 & 0.069 & 0.047 & 0.011 & 0.103 & 0.165 \\
\hline CSR1 & 0.288 & 0.322 & 0.687 & 0.073 & 0.017 & -0.011 & 0.045 & 0.415 & 0.146 & 0.097 \\
\hline CSR2 & 0.283 & 0.278 & 0.830 & 0.126 & 0.21 & 0.132 & 0.200 & 0.350 & 0.117 & 0.158 \\
\hline CSR3 & 0.314 & 0.338 & 0.843 & 0.173 & 0.096 & 0.108 & 0.187 & 0.323 & 0.099 & 0.177 \\
\hline CSR4 & 0.104 & 0.326 & 0.740 & 0.103 & 0.083 & 0.062 & -0.027 & 0.263 & 0.079 & 0.200 \\
\hline CW1 & 0.047 & 0.009 & 0.146 & 0.926 & 0.147 & 0.073 & 0.214 & 0.161 & -0.031 & -0.065 \\
\hline CW2 & -0.034 & 0.05 & 0.110 & 0.737 & 0.129 & -0.081 & 0.103 & 0.08 & 0.051 & -0.071 \\
\hline DR1 & 0.154 & 0.177 & 0.132 & 0.099 & 0.769 & 0.044 & 0.66 & 0.216 & 0.137 & 0.345 \\
\hline DR2 & 0.022 & 0.03 & 0.071 & 0.151 & 0.749 & 0.544 & 0.243 & 0.094 & 0.069 & -0.023 \\
\hline CSE1 & -0.100 & 0.018 & -0.015 & 0.094 & 0.393 & 0.881 & 0.242 & 0.043 & 0.079 & -0.123 \\
\hline CSE2 & 0.004 & 0.014 & -0.014 & -0.077 & 0.210 & 0.799 & 0.115 & -0.029 & -0.046 & -0.067 \\
\hline CSE3 & 0.048 & 0.043 & 0.271 & 0.000 & 0.254 & 0.638 & 0.294 & 0.118 & -0.056 & -0.005 \\
\hline SR1 & -0.049 & 0.064 & -0.003 & 0.189 & 0.214 & 0.399 & 0.739 & -0.022 & 0.024 & 0.224 \\
\hline SR2 & 0.063 & 0.184 & 0.181 & 0.171 & 0.365 & 0.208 & 0.857 & 0.113 & 0.126 & 0.144 \\
\hline SR3 & 0.154 & 0.177 & 0.132 & 0.099 & 0.769 & 0.044 & 0.660 & 0.216 & 0.137 & 0.364 \\
\hline ST1 & 0.157 & 0.184 & 0.389 & 0.071 & 0.185 & 0.096 & 0.120 & 0.826 & 0.052 & 0.293 \\
\hline ST2 & 0.197 & 0.235 & 0.327 & 0.182 & 0.155 & 0.002 & 0.107 & 0.822 & 0.091 & 0.187 \\
\hline FP1 & 0.231 & 0.310 & 0.144 & -0.001 & 0.106 & 0.007 & 0.151 & 0.087 & 0.769 & 0.145 \\
\hline FP2 & 0.034 & 0.117 & 0.177 & -0.089 & 0.088 & 0.026 & 0.135 & 0.124 & 0.765 & 0.393 \\
\hline FP3 & 0.220 & 0.325 & 0.185 & -0.038 & 0.005 & -0.052 & 0.152 & 0.270 & 0.737 & 0.141 \\
\hline $\mathrm{S} 1$ & 0.361 & 0.392 & 0.163 & -0.058 & 0.255 & -0.086 & 0.248 & 0.198 & 0.088 & 0.874 \\
\hline S2 & 0.309 & 0.360 & 0.175 & -0.076 & 0.246 & -0.092 & 0.300 & 0.246 & 0.222 & 0.960 \\
\hline S3 & 0.330 & 0.381 & 0.158 & -0.058 & 0.019 & -0.045 & 0.178 & 0.270 & 0.332 & 0.625 \\
\hline
\end{tabular}

Note: Values in italics are the standardized outer loadings on the constructs

Table VI. Cross loadings 
SAMPJ

11,7

\section{4}

with a second-order factor represented by three first-order factors: EMS for the CE (EMS), environmental capabilities and accounting (EA) and CSR and accountability (CSR). Similarly, the second-order factor of CS is represented by four first-order factors: waste recovery $(\mathrm{CW})$, dematerialization and recycled materials (DR), circular eco-design (CSE) and resource saving and efficiency $(\mathrm{SR})$.

Moreover, we assessed the formative measurement model for collinearity between indicators using variance inflation factor (VIF) values. The tolerance represents the amount of variance of the formative indicator not explained by the other indicators in the same factor. In our analysis, all VIF values are lower than 3.3 (Rohdin et al., 2007).

\subsection{Assessment of structural model}

Having tested the dimensional structural of the variables, PLS-SEM was used to test whether there were cause-effect relationships between environmental capabilities for the CE and CS achieved by firms, along with the mediating effect of stakeholders and financial performance. This model was formulated to answer the research questions $(R Q 1, R Q 2, R Q 3$ and $R Q 4$ ).

Bootstrapping (5,000 resamples) was used to assess the significance of the path coefficients (Hair et al., 2011). Table VIII shows that the construct called "environmental capabilities for the CE" is positively related to the level of CS (the path coefficient is positive and significant at 0.05 level of significance). Likewise, there is a positive relationship between environmental capabilities for the $\mathrm{CE}$ and financial performance $(\phi<0.01)$. These results offer empirical support for the positive relationships between CS and the variables EMS, environmental accounting practices and other management capabilities to answer research questions $R Q 1, R Q 2$ and $R Q 3$. Figure 1 shows the model results of the overall relation, namely, $R^{2}$ in the dependent variables and path coefficients.

Moreover, the results verified the mediating effect of environmental capabilities on the stakeholders-CS link by confirming that all criteria discussed by Baron and Kenny (1986) are met. We tested the mediating relationships by the following:

- establishing the positive relationship between ST and CS;

- establishing the positive relationship between ST and ECA;

- establishing the positive relationship between ECA and CS; and

- establishing that the positive relationship between ST and CS becomes weaker or insignificant once ECA (environmental capabilities for the $\mathrm{CE}$ ) is included in the model as a mediation variable.

\begin{tabular}{llccr}
\hline Second-order constructs & First-order constructs & VIF & Weight & $t$-value \\
\hline ECA & EMS & 1.175 & 0.365 & $6.144^{* * * *}$ \\
& EA & 1.265 & 0.338 & $8.002^{* * * *}$ \\
CS & CW & 1.444 & 0.603 & $9.269^{* * *}$ \\
& DR & 1.057 & 0.158 & $2.039 * *$ \\
& CSE & 1.384 & 0.357 & $8.552^{* * *}$ \\
& SR & 1.284 & 0.380 & $3.417 * * *$ \\
& & 1.179 & 0.485 & $6.340^{* * * *}$ \\
Notes: $* * * p<0.01 ; * * p<0.05$ & & & & \\
\hline
\end{tabular}

Table VII.

Higher-order constructs

Notes: *** $p<0.01 ; * * p<0.05$ 


\begin{tabular}{|c|c|c|c|c|}
\hline \multirow[b]{2}{*}{ Relations } & \multirow[b]{2}{*}{ Path coefficients } & \multirow[b]{2}{*}{$t$-value } & \multicolumn{2}{|c|}{$\begin{array}{l}\text { Percentile bootstrap } \\
95 \% \text { confidence level }\end{array}$} \\
\hline & & & Lower & Upper \\
\hline \multicolumn{5}{|l|}{ Direct effects } \\
\hline $\mathrm{ECA}=>\mathrm{CS}$ & 0.207 & $2.473 * *$ & 0.032 & 0.364 \\
\hline $\mathrm{ECA}=>\mathrm{FP}$ & 0.353 & $3.054 * * *$ & 0.106 & 0.551 \\
\hline $\mathrm{ST}=>\mathrm{ECA}$ & 0.324 & $3.679 * * * *$ & 0.150 & 0.494 \\
\hline $\mathrm{S}=>\mathrm{ECA}$ & 0.370 & $4.690 * * * *$ & 0.209 & 0.515 \\
\hline $\mathrm{MI}=>\mathrm{CS}$ & 0.111 & $1.134 \mathrm{~ns}$ & -0.089 & 0.315 \\
\hline $\mathrm{TI}=>\mathrm{CS}$ & 0.404 & $3.573^{* * *}$ & 0.162 & 0.608 \\
\hline \multicolumn{5}{|l|}{ Indirect effects } \\
\hline $\mathrm{ST}=>\mathrm{ECA}=>\mathrm{CS}$ & 0.067 & $1.999 * *$ & 0.013 & 0.149 \\
\hline $\mathrm{ST}=>\mathrm{ECA}=>\mathrm{FP}$ & 0.115 & $2.341 * *$ & 0.037 & 0.234 \\
\hline $\mathrm{S}=>\mathrm{ECA}=>\mathrm{CS}$ & 0.077 & $1.997 * * *$ & 0.010 & 0.164 \\
\hline $\mathrm{S}=>\mathrm{ECA}=>\mathrm{FP}$ & 0.131 & $2.125 * *$ & 0.027 & 0.264 \\
\hline Variances explained $R^{2}$ & \multicolumn{3}{|c|}{$0.131 \quad R^{2} \mathrm{ECA}=0.312, R^{2} \mathrm{CS}=0.151, R^{2} \mathrm{FP}=0.125$} & \\
\hline Stone-Geisser's $Q^{2}$ & \multicolumn{4}{|c|}{$Q^{2} \mathrm{ECA}=0.302, Q^{2} \mathrm{CS}=0.112, Q^{2} \mathrm{FP}=0.083$} \\
\hline
\end{tabular}

Notes: $* * * p<0.01 ; * * p<0.05$; ns $=$ not significant

Circular
economy in
businesses

1145

Table VIII.

Results of structural model



Notes: ${ }^{* *} p<0.05 ; * * p<0.01$; control variables $=\mathrm{S}, \mathrm{MI}, \mathrm{TI}$

Figure 1.

Structural model results

The results of these tests, presented in Table VIII, support these four conditions. First, the independent variable ST has a significant effect on the CS variable $(0.189, p<0.05)$ in a model that excludes environmental capabilities for the CE (ECA); second, the variable ST has a significant positive effect on the ECA variable $(0.43, p<0.01)$; third, the variable ECA has a significant positive effect on the CS variable $(0.17, p<0.05)$; and fourth, the relationship between ST and CS becomes statistically insignificant (at 0.5 level of signification) once the ECA variable is included in the model as a mediation variable $(0.14$, 
SAMPJ 11,7

$p=0.235)$. We also conducted three tests to examine the mediating effect: the Sobel test, the Aroian test and the Goodman test.

The results of these tests offer empirical support for the mediation relation (Sobel test statistic: 2.73, $p=0.038$; Aroian test statistic: 2.038, $p=0.041$; Goodman test statistic: 2.11, $p=0.034$ ). Once the conditions recommended by Baron and Kenny (1986) have been met, examining indirect effects is more effective in testing for mediation (Preacher and Hayes, 2004). As shown in Table VIII, the path coefficient that measures the indirect effect of stakeholders on CS through environmental capabilities for the CE is positive and significant (0.067, $p<0.05)$, as the direct effect was not significant; the findings reveal that environmental capabilities for the CE mediate the influence of stakeholders on CS.

These results provide empirical support for the positive relationship between stakeholder pressure and CS and thus offering an answer to $R Q 4$.

The rest of positive and significant path coefficients indicates that the firm size $(0.370$, $p<0.001)$ and industry sector $(0.404, p<0.001)$ are related with the environmental capabilities for the CE and the CS, respectively. Then, in line with previous studies, both firm size and industry sector are relevant characteristic of firms in the transition from a linear model to a circular one because it is a factor that facilitates eco-innovative processes.

\subsection{Discussion}

In this paper, we have addressed the different aspects of the environmental capabilities of firms that might influence the extent to which the CE-related practices are introduced in businesses, which in this study is briefly defined as CS. Based on the literature reviewed in this paper, we propose a construct to measure dynamic capabilities for the $\mathrm{CE}$ that integrates different competences of firms that have not been discussed before in the same framework of analysis, in response to Katz Gerro and López Sintas (2019), who point out the necessity of qualitative research to study dynamic capabilities through firms.

To this end, we take the dynamic capabilities theoretical approach, which has to date been scarcely been used for the CE. The dynamic capabilities analysis has been adopted by an increasing number of studies on eco-innovation (Gabler et al., 2015; Kiefer et al., 2018; PortilloTarragona et al., 2018) and in environmental strategy (Daddi et al., 2018; Garcés-Ayerbe and Cañón-de-Francia, 2017), but only a few authors have focused their CE-related analysis on this theoretical framework (Katz Gerro and López Sintas, 2019) probably because of the difficulty of obtaining specific information about the circular practices carried out by businesses. In this study, we measured some of the competencies that are applied to CE-related practices by firms of different sectors and sizes. Thus, the approach taken by Katz Gerro and López Sintas (2019), which is applied only to Small and Medium Enterprises (SMEs), was extended because our sample also included larger companies and different environmental capabilities.

As a general remark, the importance of dynamic capabilities indicated by other authors (Eisenhardt and Martin, 2000; Gabler et al., 2015; Teece et al., 1997) was also corroborated in this study, as was the relevance of managerial proactivity for eco-innovation projects (Chang, 2013; Del Río et al., 2016) and the relevance of the ability to implement advanced environmental management systems (Demirel and Kesidou, 2011; Horbach, 2008; Wagner, 2007).

In detail, the obtained results suggest positive relationships between the CS of businesses and their environmental capabilities for the CE, which, in this study, are measured through different variables focused on the EMSs adopted by firms, their environmental accounting practices and their levels of CSR and accountability. To the best of our knowledge, no similar studies exist that could allow us to discuss the obtained results. However, some of 
the studies carried out to date and mentioned in the background allow us to partially address the discussion of the results for each research question.

Based on the dynamic capabilities theoretical arguments, in the context of $R Q 1$, our study analyzed formal EMSs to demonstrate their positive impact on the level of a CE achieved by firms. This positive relationship confirms that EMSs are standardized processes that contribute to the introduction of a CE, just like they do in the case of ecoinnovation (Amores-Salvadó et al., 2015). These results reinforce those of previous studies that demonstrate the positive influence of EMSs as specific environmental capabilities for eco-innovation - in line with Amores-Salvadó et al. (2015) - but they also open a new line of inquiry for the literature on the CE. Although this result may seem intuitive, our analysis contributes to the specific knowledge about the impact of EMSs on the CE in businesses because this has not, to date, been empirically investigated. In addition, we are able to offer new insights into arguments that consider EMSs could also restrict firms by making them focus on exploiting present production systems rather than exploring new systems based on radical innovations (Könnölä and Unruh, 2007).

In the context of accounting and other managerial environmental competences applied by firms to introduce the CE, the approach to the study of EMA under the theoretical framework of dynamic capabilities is quite original. This approach constitutes this study's innovation, because $R Q 2$ allows us to explore the positive relationship between the CS of businesses and different variables designed to measure those endogenous EMA methods that firms apply to carry out CE-related activities. In this study, the EMA is measured through an enhanced construct. In previous studies, EMA has been associated with waste and recycling management (Qian et al., 2011); physical flows of energy, water and materials (including wastes); monetary information on environment-related costs, earnings and savings; and also indirect environmental information in overheads.

To date, little research has examined how to manage waste and material recycling through the EMA, but it can be expected that CE-related activities' introduction in businesses will involve changes in their environmental information systems and entail specific modification of the mechanisms of eco-control and sustainability control as defined by Qian et al. (2018). Thus, our study reinforces the idea that the use of EMA tools can be associated with CE management in businesses and the disclosure quality, expanding carbon emissions management studies (Qian et al., 2018).

The EMA-related capabilities measured in this paper include the availability of human resources for environmental management activities, which is also positively related to the CS of firms, confirming the result obtained for eco-innovation (Scarpellini et al., 2017). This result is also partially connected with pro-environmental managers' personal values, which were analyzed by Luque-Vílchez et al. (2019) to ensure the quality of environmental disclosure. From another perspective, the attitude of management toward the environment and CSR has been considered of interest (Cameron, 2011; Cheng et al., 2013; Groves and LaRocca, 2011; Pless and Maak, 2011; Del Río et al., 2016), because it allows an organization to align itself with changes in its natural and business environments and to combine external information with the organization's internal knowledge (De Marchi, 2012).

In this line of inquiry, the level of CSR and the reporting of environmental information and its quality are also identified in this study as relevant factors in the introduction of the $\mathrm{CE}$ in the micro-field (RQ3). In particular, these achievements represent a contribution to the $\mathrm{CE}$ research community and support and enhance the conclusions reached by Stewart and Niero (2018). It should be noted that the level of accountability of the surveyed forms is higher when their CS increases, in line with the results obtained for eco-innovation (Marco et al., 2019) and other green sectors (Marco-Fondevila et al., 2018). 
SAMPJ

11,7

1148

The results achieved here also make a novel contribution to our understanding of the relationship between the $\mathrm{CE}$ and stakeholder pressure, which has a mediating effect on the CS of firms, adding new insights to recent studies on this topic at the micro-level. Stakeholder pressure has been demonstrated, through case studies, to positively affect the adoption of the CE by firms (Witjes and Lozano, 2016), but this effect is mediated when a more general analysis of the CS of firms is performed in a larger sample of businesses that has not necessarily adopted the circular business model (RQ4). In line with Zubeltzu-Jaka et al. (2018), CSR elements are necessary and fundamental to the establishment of a business model that satisfies the needs of the highest possible number of stakeholders (including shareholders), with the objective of increasing, in the long term, the value of the company for those same stakeholders. This statement can also be considered as summarizing the results obtained in our study regarding the relationship between the CS and the stakeholders.

Finally, regarding the relationship between the different CE-related activities, we cannot demonstrate that there is interdependence between specific activities and certain capabilities, but we can point out that the CS is related to the capabilities studied, partially confirming arguments about the interrelations indicated by others authors (Katz Gerro and López Sintas, 2019).

\section{Conclusions}

In this paper, a quantitative study of the specific endogenous capabilities that businesses apply when introducing the $\mathrm{CE}$ is conducted within the framework of the dynamic capabilities perspective. Our main purpose is to enhance previous research on the $\mathrm{CE}$ at the micro-level by exploring whether the adoption of different CE-related practices is reinforced through four specific capabilities of businesses: the adoption of EMS, their environmental accounting practices and the human resources involved in environmental management, the CSR and the level of accountability or the stakeholder pressure on the firms. The applied research approach is not innovative in itself, but the measurement of the CE-related activities and different competences of firms using the same framework of analysis constitutes a contribution of this study. In addition, the dynamic capabilities theoretical approach has rarely been adopted in the academic $\mathrm{CE}$ literature to date.

A central finding of this study is that CE-related activities introduced by businesses are influenced by the analyzed capabilities that also improve the environmental and financial performance of firms in a $\mathrm{CE}$ framework. In addition, we show the mediating role of stakeholders in introducing the $\mathrm{CE}$ in businesses, which is a little explored line of inquiry, as this relationship has not been widely analyzed for the CE.

The measurement of the level of $\mathrm{CE}$ of an organization is a topic of interest at present because the specific indicators that can be applied to firms are still under development. Our study defines the CS of businesses through measuring activities and investments that are being developed by firms at present and that are considered as relevant in terms of the CE. This allows for partially implementing a circular business model, and the measurement of the CE-related activities can be applied to a large number of firms, regardless of their size or the industry in which they operate. The new insights proposed in this study facilitate the measurement of the introduction of the $\mathrm{CE}$ and make inferences regarding a research area that has been, thus far, little explored.

In addition, the obtained results can help overcome the limitations of conventional accounting approaches and incorporates a much broader scale of environmental information that can be applied to $\mathrm{CE}$ practices. In this regard, this study contributes to bridging the gap between academic research focused on environmental accounting and that investigating the introduction of the $\mathrm{CE}$ in businesses. 
For business scholars, we provide empirical support to show that the adoption of the CErelated activities by firms behaves similarly to the progressive introduction of eco-innovation. Following the research approach initiated by other authors in the micro-field, we offer new insights that can help future business researchers study the endogenous resources and capabilities of firms for the deployment of the $\mathrm{CE}$. One challenge facing academics is to bring the discussion around the $\mathrm{CE}$ into conversation with research into sustainability accounting to develop a still-incipient debate, in which we have intervened through this study. New investigations are needed, however, in particular on the financial performance of firms who introduce the $\mathrm{CE}$ in their business strategy framework.

We offer insights to practitioners who wish to understand how to manage the specific competences that integrate the capabilities applied to the $\mathrm{CE}$. The environmental management activities and the availability of specialized human resources have been shown to be relevant for the implementation of a circular business model. Thus, the results obtained can be applied to decision-making processes regarding investments in ecoinnovation, eco-design and the improvement of the CS of firms that will need specific capabilities of businesses. Practitioners gain insights for integrating capabilities related to $\mathrm{CE}$ (indicators, what to report, what capabilities and measurement techniques). Managers should seek efforts to strategically bundle EMA and accountability practices in their CErelated activities. Findings, therefore, highlight the need for firms to prioritize the sustainability accounting implementation that lead to higher levels of CS. In summary, this methodological approach provides metrics that allow firms, included SMEs, to measure and report on CE-related activities, and these metrics can be partially applied depending on those practices that have been introduced in each firm.

For policymakers, a better understanding of the introduction of the $\mathrm{CE}$ in businesses will contribute to the design of policies that can enhance the CE's deployment in a territory, for example, by providing tools and measures to help companies close material loops, control their efficiency and invest in new technologies to adopt new, CE-related activities. The proposed methodologies could be used to promote the $\mathrm{CE}$ in other geographic areas and to influence the setting up of regional priorities depending on the CE-related practices adopted by the firms located in the territory.

The main limitations of this study are related to the measurement of the degree of circularity, which accounts for only some of the activities carried out by businesses, and the characteristics of the sample. The use of a higher number of firms in different regional contexts could provide an additional perspective on the issues considered in this study. Another limitation of this study is the scarce amplitude of the variable construct applied to the measurement of the EMA and the other CE-related activities.

Furthermore, it is important to also investigate trends over a longer period, to obtain longitudinal data relating to the current development of specific dynamic capabilities applied to the CE by businesses. Despite the fact that the discriminant validity criterion was met, the authors recognize that the objective minimum value of the cross loads was not achieved for three variables, which is a limitation to analyzing in depth the information provided by the respondents about the resources/products managed for the dematerialization and the use of recycled materials.

Future research should try to overcome these limitations and reach a better understanding of the dynamic capabilities specifically needed for the adoption of the CE, which requires changes in the business model and in the EMA because of the monitoring and measurement of flows of raw materials and resources, especially as the progressive introduction of increasingly far-reaching collaborative models is expected. 
1. Further information about the project and the selected firms at: https://socioene.unizar.es/ proyectos/recoinno/empresas.html (assessed on July 2019).

2. See www.prtr-es.es/documentos/documentos-mejores-tecnicas-disponibles (accessed June 2016).

3. Balance Sheet Analysis System (SABI) [online database]. 2016. Madrid.

\section{0}

\section{References}

Aboelmaged, M. (2018), "The drivers of sustainable manufacturing practices in Egyptian SMEs and their impact on competitive capabilities: a PLS-SEM model", Journal of Cleaner Production, Vol. 175 No. 1, pp. 207-221.

Adams, C. (2002), "Internal organisational factors influencing corporate social and ethical reporting: beyond current theorising", Accounting, Auditing and Accountability Journal, Vol. 15 No. 2, pp. 223-250.

Albelda, E. (2011), "The role of management accounting practices as facilitators of the environmental management: evidence from EMAS organisations", Sustainability Accounting, Management and Policy Journal, Vol. 2 No. 1, pp. 76-100.

Ambrosini, V., Bowman, C. and Collier, N. (2009), "Dynamic capabilities: an exploration of how firms renew their resource base", British Journal of Management, Vol. 20 No. 1, pp. 9-24.

Amores-Salvadó, J., Martin-de Castro, G. and Navas-López, J.E. (2015), "The importance of the complementarity between environmental management systems and environmental innovation capabilities: a firm level approach to environmental and business performance benefits", Technological Forecasting and Social Change, Vol. 96 No. 1, pp. 288-297.

Aragón-Correa, J.A. and Rubio-López, E. (2007), "Proactive corporate environmental strategies: myths and misunderstandings", Long Range Planning, Vol. 40 No. 3, pp. 357-381.

Aragón-Correa, J.A. and Sharma, S. (2003), "A contingent resource-based view of proactive corporate environmental strategy", Academy of Management Review, Vol. 28 No. 1, pp. 71-88.

Aranda-Usón, A., M. Moneva, J., Portillo-Tarragona, P., Llena-Macarulla, F., Moneva, J.M., PortilloTarragona, P. and Llena-Macarulla, F. (2018), "Measurement of the circular economy in businesses: impact and implications for regional policies", Economics and Policy of Energy and the Environment, Vol. 2 No. 1, pp. 187-205.

Aranda-Usón, A., Portillo-Tarragona, P., Marín-Vinuesa, L.M. and Scarpellini, S. (2019), "Financial resources for the circular economy: a perspective from businesses", Sustainability, Vol. 11 No. 3, pp. 1-23.

Aravind, D. and Christmann, P. (2011), "Decoupling of standard implementation from certification: does quality of ISO 14001 implementation affect facilities' environmental performance?”, Business Ethics Quarterly, Vol. 21 No. 1, pp. 73-102.

Bagozzi, R. and Yi, Y. (1988), "On the evaluation of structural equation models", Journal of the Academy of Marketing Science, Vol. 16 No. 1, pp. 74-94.

Banaite, D. and Tamosiuniene, R. (2016), "Sustainable development: the circular economy indicators' selection model”, Journal of Security and Sustainability Issues, Vol. 6 No. 2, pp. 489-499.

Barney, J.B. (1991), "Firm resources and sustained competitive advantage", Journal of Management, Vol. 17 No. 1, pp. 99-120.

Barney, J.B. (2001), "Is the resource-based 'view' a useful perspective for strategic management research? Yes", The Academy of Management Review, Vol. 26 No. 1, pp. 41-56.

Baron, R.M. and Kenny, D.A. (1986), "The moderator-mediator variable distinction in social psychological research. conceptual, strategic, and statistical considerations", Journal of Personality and Social Psychology, Vol. 51 No. 6, pp. 1173-1182. 
Bartolomeo, M., Bennett, M., Bouma, J.J., Heydkamp, P., James, P. and Wolters, T. (2000), "Environmental management accounting in Europe: current practice and future potential", European Accounting Review, Vol. 9 No. 1, pp. 31-52, available at: https://doi.org/10.1080/096381800407932

Bocken, N.M.P., Short, S.W., Rana, P. and Evans, S. (2014), "A literature and practice review to develop sustainable business model archetypes”, Journal of Cleaner Production, Vol. 65 No. 1, pp. $42-56$.

Bocken, N.M.P., de Pauw, I., Bakker, C. and van der Grinten, B. (2016), "Product design and business model strategies for a circular economy", Journal of Industrial and Production Engineering, Vol. 33 No. 5, pp. 308-320.

Boiral, O. (2007), “Corporate greening through ISO 14001: a rational myth?”, Organization Science, Vol. 18 No. 1, pp. 127-146.

Boiral, O., Guillaumie, L., Heras-Saizarbitoria, I. and Tayo Tene, C.V. (2018), “Adoption and outcomes of ISO 14001: a systematic review”, International Journal of Management Reviews, Vol. 20 No. 2, pp. 411-432.

Borrello, M., Caracciolo, F., Lombardi, A., Pascucci, S. and Cembalo, L. (2017), “Consumers' perspective on circular economy strategy for reducing food waste", Sustainability (Switzerland), Vol. 9 No. 141, pp. 1-18.

Burritt, R.L., Herzig, C., Schaltegger, S. and Viere, T. (2019), "Diffusion of environmental management accounting for cleaner production: evidence from some case studies", Journal of Cleaner Production, Vol. 224, pp. 479-491, doi: 10.1016/j.jclepro.2019.03.227.

Burritt, R. and Schaltegger, S. (2001), "Eco-efficiency in corporate budgeting", Environmental Management and Health, Vol. 12 No. 2, pp. 158-174.

Burritt, R.L. and Schaltegger, S. (2010), "Sustainability accounting and reporting: fad or trend?", Accounting, Auditing and Accountability Journal, Vol. 23 No. 7, pp. 829-846.

Cameron, K. (2011), "Responsible leadership as virtuous leadership”, Journal of Business Ethics, Vol. 98, pp. 25-35.

Chang, C.-Y. (2013), "A critical analysis of recent advances in the techniques for the evaluation of renewable energy projects", International Journal of Project Management, Vol. 31 No. 7, pp. 1057-1067.

Chang, C. and Chen, Y. (2013), "Green organizational identity and green innovation", Management Decision, Vol. 51 No. 5, pp. 1056-1070.

Cheng, C.-F.F., Chang, M.-L.L. and Li, C.-S.S. (2013), "Configural paths to successful product innovation”, Journal of Business Research, Vol. 66 No. 12, pp. 2561-2573.

Collins, E., Lawrence, S., Roper, J. and Haar, J. (2011), Sustainability and the Role of the Management Accountant: Research Executive Summary Series, Vol. 7, Chartered Institute of Management Accountants (CIMA), London.

Correa, C., Esther, R., Pérez, A., Fenech, F.C., Correa Ruiz, M., del, C., Albelda Pérez, E. and Carrasco Fenech, F. (2013), "La sostenibilidad y El Papel de La contabilidad En La Gestión Del Cambio climático y La ecoinnovación En La Pyme”, Cuadernos Económicos de Ice, Vol. 1 No. 86, p. 53.

Cullen, D.D. and Whelan, C. (2006), "Environmental management accounting: the state of play", Journal of Business and Economics Research, Vol. 4 No. 10, pp. 1-6.

Daddi, T., Nucci, B. and Iraldo, F. (2017), "Using life cycle assessment (LCA) to measure the environmental benefits of industrial symbiosis in an industrial cluster of SMEs", Journal of Cleaner Production, Vol. 147 No. 1, pp. 157-164.

Daddi, T., Testa, F., Frey, M. and Iraldo, F. (2016), "Exploring the link between institutional pressures and environmental management systems effectiveness: an empirical study", Journal of Environmental Management, Vol. 183, pp. 647-656.

Daddi, T., Todaro, N.M., De Giacomo, M.R. and Frey, M. (2018), "A systematic review of the use of organization and management theories in climate change studies", Business Strategy and the Environment, Vol. 27 No. 4, pp. 456-474. 
SAMPJ 11,7

Del Río, P., Carrillo-Hermosilla, J., Könnölä, T. and Bleda, M. (2012), "Business strategies and capacities for eco-innovation", in ISPIM (Ed.), The XXIII ISPIM Conference - Action for Innovation: Innovating from Experience, Barcelona, pp. 1-12, available at: https://doi.org/10.2139/ssrn.2021289

Del Río, P., Carrillo-Hermosilla, J., Könnölä, T. and Bleda, M. (2016), "Resources, capabilities and competences for eco- innovation", Technological and Economic Development of Economy, Vol. 22 No. 2, pp. 274-292.

De Marchi, V. (2012), "Environmental innovation and R\&D cooperation: empirical evidence from Spanish manufacturing firms", Research Policy, Vol. 41 No. 3, pp. 614-623.

Demirel, P. and Kesidou, E. (2011), "Stimulating different types of eco-innovation in the UK: government policies and firm motivations", Ecological Economics, Vol. 70 No. 8, pp. 1546-1557.

De los Rios, I.C. and Charnley, F.J.S. (2017), "Skills and capabilities for a sustainable and circular economy: the changing role of design", Journal of Cleaner Production, Vol. 160 No. 1, pp. 109-122.

Di Maio, F. and Rem, P.C. (2015), "A robust indicator for promoting circular economy through recycling”, Journal of Environmental Protection, Vol. 6 No. 10, pp. 1095-1104.

Ding, M. (2014), "Supply chain collaboration toward eco-innovation: an SEM analysis of the inner mechanism", Proceedings of 2014 IEEE International Conference on Service Operations and Logistics, and Informatics, SOLI 2014, pp. 129-134.

Eisenhardt, K.M. and Martin, J.A. (2000), "Dynamic capabilities: what are they?", Strategic Management Journal, Vol. 21 Nos 10/11, pp. 1105-1121.

Essid, M. and Berland, N. (2018), "Adoption of environmental management tools: the dynamic capabilities contributions", Sustainability Accounting, Management and Policy Journal, Vol. 9 No. 3, pp. 229-252.

European Commission (2014), "Communication from the commission to the european parliament, the council, the European economic and social committee and the committee of the regions", Towards a Circular Economy: A Zero Waste Programme for Europe, COM, 398 Final, European Commission, pp. 1-14.

European Commission (2015), "An EU action plan for the circular economy”, COM, 614 Final.

European Commission (2017), "The role of waste-to-energy in the circular economy", Communication From the Commission To the European Parliament, the Council, The European Economic and Social Committee and the Committee of the Regions- COM, p. 34.

European Commission (2018a), "Communication from the Commission to the European Parliament, the Council, the European Economic and Social Committee snd the Committee of the Regions: A European Strategy for Plastics in a Circular Economy”, COM, 28 Final, Vol. SWD No. 1, pp. 1-18.

European Commission (2018b), "EU-Report on Critical Raw Materials and the Circular Economy", SWD, 36 final.

Figge, F., Givry, P., Canning, L., Franklin-Johnson, E. and Thorpe, A. (2017), "Eco-efficiency of virgin resources: a measure at the interface between micro and macro levels", Ecological Economics, Vol. 138, pp. 12-21.

Franco, M.A. (2017), "Circular economy at the micro level: a dynamic view of incumbents' struggles and challenges in the textile industry", Journal of Cleaner Production, Vol. 168 No. 1, pp. 833-845.

Gabler, C.B., Richey, R.G. and Rapp, A. (2015), "Developing an eco-capability through environmental orientation and organizational innovativeness", Industrial Marketing Management, Vol. 45 No. 1, pp. 151-161.

Garcés-Ayerbe, C. and Cañón-de-Francia, J. (2017), "The relevance of complementarities in the study of the economic consequences of environmental proactivity: analysis of the moderating effect of innovation efforts", Ecological Economics, Vol. 142, pp. 21-30. 
Garcés-Ayerbe, C., Rivera-Torres, P., Suárez-Perales, I. and Leyva-de la Hiz, D.I. (2019), "Is it possible to change from a linear to a circular economy? An overview of opportunities and barriers for european small and medium-sized enterprise companies", International Journal of Environmental Research and Public Health, Vol. 16 No. 5, pp. 1-15.

Ghisellini, P., Cialani, C. and Ulgiati, S. (2016), "A review on circular economy: the expected transition to a balanced interplay of environmental and economic systems", Journal of Cleaner Production, Vol. 114 No. 1, pp. 11-32.

Ghisellini, P., Ji, X., Liu, G. and Ulgiati, S. (2018), "Evaluating the transition towards cleaner production in the construction and demolition sector of China: a review", Journal of Cleaner Production, Vol. 195 No. 1, pp. 418-434.

Gibson, K.C. and Martin, B.A. (2004), "Demonstrating value through the use of environmental management accounting", Environmental Quality Management, Vol. 13 No. 3, pp. 45.

Goodhue, D., Lewis, W. and Thompson, R. (2018), "Does PLS have advantages for small sample size or non-normal data?”, MIS Quarterly, Vol. 36 No. 3, pp. 981-1001.

Groves, K.S. and LaRocca, M.A. (2011), "An empirical study of leader ethical values, transformational and transactional leadership, and follower attitudes toward corporate social responsibility", Journal of Business Ethics, Vol. 103 No. 4, pp. 511-528.

Haas, W., Krausmann, F., Wiedenhofer, D. and Heinz, M. (2015), "How circular is the global economy? An assessment of material flows, waste production, and recycling in the European union and the world in 2005", Journal of Industrial Ecology, Vol. 19 No. 5, pp. 765-777.

Hair, J.F., Ringle, C.M. and Sarstedt, M. (2011), "PLS-SEM: indeed a silver bullet", Journal of Marketing Theory and Practice, Vol. 19 No. 2, pp. 139-152.

Hair, J., Risher, J., Sarstedt, M. and Ringle, C. (2019), "When to use and how to report the results of PLSSEM", European Business Review, Vol. 31 No. 1, pp. 2-24, available at: https://doi.org/10.1108/ EBR-11-2018-0203

Hamann, P.M., Schiemann, F., Bellora, L. and Guenther, T.W. (2013), "Exploring the dimensions of organizational performance: a construct validity study", Organizational Research Methods, Vol. 16 No. 1, pp. 67-87.

Henseler, J., Hubona, G. and Ray, P.A. (2016), "Using PLS path modeling in new technology research: updated guidelines”, Industrial Management and Data Systems, Vol. 116 No. 1, pp. 2-20.

Hong, J., Zhang, Y. and Ding, M. (2018), "Sustainable supply chain management practices, supply chain dynamic capabilities, and enterprise performance", Journal of Cleaner Production, Vol. 172, pp. 3508-3519.

Horbach, J. (2008), "Determinants of environmental innovation - new evidence from German panel data sources", Research Policy, Vol. 37 No. 1, pp. 163-173.

Huysman, S., De Schaepmeester, J., Ragaert, K., Dewulf, J. and De Meester, S. (2017), "Performance indicators for a circular economy: a case study on post-industrial plastic waste", Resources, Conservation and Recycling, Vol. 120 No. 1, pp. 46-54.

Iñigo, E.A. and Albareda, L. (2016), "Understanding sustainable innovation as a complex adaptive system: a systemic approach to the firm”, Journal of Cleaner Production, Vol. 126.

Jawahir, I.S. and Bradley, R. (2016), "Technological elements of circular economy and the principles of 6R-based closed-loop material flow in sustainable manufacturing", Procedia Cirp, Vol. 40, pp. 103-108.

Kabongo, J.D. and Boiral, O. (2017), "Doing more with less: building dynamic capabilities for ecoefficiency", Business Strategy and the Environment, Vol. 26 No. 7, pp. 956-971.

Katsoulakos, T. and Katsoulacos, Y. (2007), "Strategic management, corporate responsibility and stakeholder management integrating corporate responsibility principles and stakeholder approaches into mainstream strategy: a stakeholder-oriented and integrative strategic 
SAMPJ 11,7 management framework", Corporate Governance: The International Journal of Business in Society, Vol. 7 No. 4, pp. 355-369.

Katz Gerro, T. and López Sintas, J. (2019), "Mapping circular economy activities in the European union: patterns of implementation and their correlates in small and medium-sized enterprises", Business Strategy and the Environment, Vol. 28 No. 1, pp. 485-496.

Kiefer, C.P., Del Río González, P. and Carrillo-Hermosilla, J. (2018), "Drivers and barriers of ecoinnovation types for sustainable transitions. a quantitative perspective", Business Strategy and the Environment, Vol. 28 No. 1, pp. 1-38.

Kirchherr, J., Reike, D. and Hekkert, M. (2017), “Conceptualizing the circular economy: an analysis of 114 definitions”, Resources, Conservation and Recycling, Vol. 127 No. 1, pp. 221-232.

Könnölä, T. and Unruh, G.C. (2007), "Really changing the course: the limitations of environmental management systems for innovation”, Business Strategy and the Environment, Vol. 16 No. 8, pp. 525-537. No.

Korhonen, J., Honkasalo, A. and Seppälä, J. (2018), “Circular economy: the concept and its limitations”, Ecological Economics, Vol. 143 No. 1, pp. 37-46.

Lewandowski, M. (2016), "Designing the business models for circular economy-towards the conceptual framework”, Sustainability (Switzerland), Vol. 8 No. 1, pp. 1-28.

Lieder, M. and Rashid, A. (2016), "Towards circular economy implementation: a comprehensive review in context of manufacturing industry", Journal of Cleaner Production, Vol. 115, pp. 36-51.

Linder, M. and Williander, M. (2017), "Circular business model innovation: inherent uncertainties", Business Strategy and the Environment, Vol. 26 No. 2, pp. 182-196.

Linder, M., Sarasini, S. and van Loon, P. (2017), "A metric for quantifying product-level circularity”, Journal of Industrial Ecology, Vol. 21 No. 3, pp. 545-558.

Liu, Y. and Bai, Y. (2014), “An exploration of firms' awareness and behavior of developing circular economy: an empirical research in China”, Resources, Conservation and Recycling, Vol. 87, pp. 145-152.

Llena, F., Moneva, J.M. and Hernandez, B. (2007), "Environmental disclosures and compulsory accounting standards: the case of Spanish annual reports", Business Strategy and the Environment, Vol. 16 No. 1, pp. 50-63.

Luque-Vílchez, M., Mesa-Pérez, E., Husillos, J. and Larrinaga, C. (2019), "The influence of proenvironmental managers' personal values on environmental disclosure”, Sustainability Accounting, Management and Policy Journal, Vol. 10 No. 1, pp. 41-61.

Marco, M., Moneva, J.M. and Scarpellini, S. (2019), "Environmental disclosure and eco-innovation interrelation. The case of Spanish firms”, Spanish Accounting Review, Vol. 22 No. 1, pp. 71-85.

Marco-Fondevila, M., Moneva Abadía, J.M. and Scarpellini, S. (2018), "CSR and green economy: determinants and correlation of firms' sustainable development”, Corporate Social Responsibility and Environmental Management, Vol. 25 No. 5, pp. 1-16.

Marín-Vinuesa, L.M., Scarpellini, S., Portillo-Tarragona, P. and Moneva, J.M. (2018), "The impact of ecoinnovation on performance through the measurement of financial resources and green patents", Organization and Environment, p. 108602661881910.

Mathews, J.A. and Tan, H. (2011), "Progress toward a circular economy in China", Journal of Industrial Ecology, Vol. 15 No. 3, pp. 435-457.

Mathews, M.R. (2008), "Further thoughts on mega-accounting and the need for standards", Issues in Social and Environmental Accounting, Vol. 2 No. 2, pp. 158-175.

Mathews, J.A. and Tan, H. (2016), “Lessons from china”, Nature, Vol. 531 No. 7595, pp. 440-442.

Mentink, B. (2014), Circular Business Model Innovation: A Process Framework and a Tool for Business Model Innovation in a Circular Economy, Delft University of Technology, Delft, p. 167. 
Merli, R., Preziosi, M. and Acampora, A. (2018), "How do scholars approach the circular economy? A systematic literature review", Journal of Cleaner Production, Vol. 178 No. 1, pp. 703-722.

Murray, A., Skene, K. and Haynes, K. (2017), "The circular economy: an interdisciplinary exploration of the concept and application in a global context", Journal of Business Ethics, Vol. 140 No. 3, pp. 369-380.

Circular
economy in
businesses

1155

Ormazabal, M., Prieto-Sandoval, V., Jaca, C. and Santos, J. (2016), “An overview of the circular economy among SMEs in the Basque country: a multiple case study", Journal of Industrial Engineering and Management, Vol. 9 No. 5, pp. 1047-1058.

Ormazabal, M., Prieto-Sandoval, V., Puga-Leal, R. and Jaca, C. (2018), "Circular economy in Spanish SMEs: challenges and opportunities", Journal of Cleaner Production, Vol. 185, pp. 157-167.

Park, M.S., Bleischwitz, R., Han, K.J., Jang, E.K. and Joo, J.H. (2017), "Eco-innovation indices as tools for measuring eco-innovation", Sustainability (Sustainability), Vol. 9 No. 12, pp. 1-28.

Pauliuk, S. (2018), "Critical appraisal of the circular economy standard BS 8001:2017 and a dashboard of quantitative system indicators for its implementation in organizations", Resources, Conservation and Recycling, Vol. 129 No. 1, pp. 81-92.

Pieroni, M.P.P., McAloone, T.C. and Pigosso, D.C.A. (2019), "Business model innovation for circular economy and sustainability: a review of approaches", Journal of Cleaner Production, Vol. 2015 No. 1, pp. 198-216.

Pless, N. and Maak, T. (2011), "Responsible leadership: pathways to the future", Journal of Business Ethics, Vol. 98, pp. 3-13.

Podsakoff, P.M. and Organ, D.W. (1986), "Self-reports in organizational research: problems and prospects”, Journal of Management, Vol. 12 No. 4, pp. 531-544.

Pomponi, F. and Moncaster, A. (2017), "Circular economy for the built environment: a research framework", Journal of Cleaner Production, Vol. 143, pp. 710-718.

Portillo-Tarragona, P., Scarpellini, S., Moneva, J., Valero-Gil, J. and Aranda-Usón, A. (2018), "Classification and measurement of the firms' resources and capabilities applied to ecoinnovation projects from a resource-based view perspective", Sustainability, Vol. 10 No. 9, p. 3161.

Pratt, K., Lenaghan, M. and Mitchard, E.T.A. (2016), "Material flows accounting for Scotland shows the merits of a circular economy and the folly of territorial carbon reporting", Carbon Balance and Management, Vol. 11 No. 1, pp. 1-15.

Preacher, K.J. and Hayes, A.F. (2004), "SPSS and SAS procedures for estimating indirect effects in simple mediation models", Behavior Research Methods, Instruments, and Computers, Vol. 36 No. 4, pp. 717-731.

Prieto-Sandoval, V., Jaca, C. and Ormazabal, M. (2018), “Towards a consensus on the circular economy”, Journal of Cleaner Production, Vol. 179, pp. 605-615.

Qian, W., Burritt, R. and Monroe, G. (2011), "Environmental management accounting in local government: a case of waste management", Accounting, Auditing and Accountability Journal, Vol. 24 No. 1, pp. 93-128, doi: 10.1108/09513571111098072.

Qian, W., Hörisch, J. and Schaltegger, S. (2018), "Environmental management accounting and its effects on carbon management and disclosure quality", Journal of Cleaner Production, Vol. 174, pp. 1608-1619.

Ranta, V., Aarikka-Stenroos, L., Ritala, P. and Mäkinen, S.J. (2018), "Exploring institutional drivers and barriers of the circular economy: a cross-regional comparison of China, the US, and Europe", Resources, Conservation and Recycling, Vol. 135, pp. 70-82.

Rehfeld, K.-M.M., Rennings, K. and Ziegler, A. (2007), "Integrated product policy and environmental product innovations: an empirical analysis”, Ecological Economics, Vol. 61 No. 1, pp. 91-100. 
Republic of China (2008), "Circular economy promotion law of the Peoplés Republic of China (english version)", Translation by lawinfochina.com, available at: https://ppp.worldbank.org/public-privatepartnership/sites/ppp.worldbank.org/files/documents/China_CircularEconomyLawEnglish.pdf

Ringle, C.M. Wende, S. and Decker, J.M. (2015), "Smart PLS3”, SmartPLS GmbH, available at: https:// doi.org/10.15358/9783800644377_564

Rivera-Torres, P., Garces-Ayerbe, C., Scarpellini, S. and Valero-Gil, J. (2015), "Pro-environmental change and short- to mid-term economic performance: the mediating effect of organisational design change", Organization and Environment, Vol. 28 No. 3, pp. 307-327.

Rohdin, P., Thollander, P. and Solding, P. (2007), "Barriers to and drivers for energy efficiency in the Swedish foundry industry”, Energy Policy, Vol. 35 No. 1, pp. 672-677.

Ruiz-Romero, S., Colmenar-Santos, A., Gil-Ortego, R. and Molina-Bonilla, A. (2013), "Distributed generation: the definitive boost for renewable energy in Spain”, Renewable Energy, Vol. 53, pp. 354-364.

Russo, M.V. (2009), "Explaining the impact of ISO 14001 on emission performance: a dynamic capabilities perspective on process and learning", Business Strategy and the Environment, Vol. 18 No. 5, pp. 307-319.

Sarstedt, M., Hair, J.F., Ringle, C.M., Thiele, K.O. and Gudergan, S.P. (2016), "Estimation issues with PLS and CBSEM: where the bias lies!", Journal of Business Research, Vol. 69 No. 10, pp. 3998-4010.

Scarpellini, S., Portillo-Tarragona, P. and Marin-Vinuesa, L.M. (2019), "Green patents: a way to guide the eco-innovation success process?”, Academia Revista Latinoamericana de Administración, Vol. 32 No. 2, pp. 225-243.

Scarpellini, S., Ortega-Lapiedra, R., Marco-Fondevila, M. and Aranda-Usón, A. (2017), "Human capital in the eco-innovative firms: a case study of eco-innovation projects", International Journal of Entrepreneurial Behavior and Research, Vol. 23 No. 6, pp. 919-933.

Scott, J.T. (2013), The Sustainable Business: A Practitioner's Guide to Achieving Long - Term Profitability and Competitiveness, 1st ed., edited by Routledge, Tylor and Francis Group, London, doi: $10.4324 / 9781351276603$.

Sihvonen, S. and Partanen, J. (2017), "Eco-design practices with a focus on quantitative environmental targets: an exploratory content analysis within ICT sector", Journal of Cleaner Production, Vol. 143, pp. 769-783.

Stewart, R. and Niero, M. (2018), "Circular economy in corporate sustainability strategies: a review of corporate sustainability reports in the fast-moving consumer goods sector", Business Strategy and the Environment, Vol. 27 No. 7, pp. 1005-1022.

Tanc, A. and Gokoglan, K. (2015), "The impact of environmental accounting on strategic management accounting: a research on manufacturing companies", International Journal of Economics and Financial Issues, Vol. 5 No. 2, pp. 566-573.

Teece, D.J. (2007), "Explicating dynamic capabilities: the nature and microfoundations of (sustainable) enterprise performance”, Strategic Management Journal, Vol. 28 No. 13, pp. 1319-1350.

Teece, D.J., Pisano, G. and Shuen, A. (1997), "Dynamic capabilities and strategic management", Strategic Management Journal, Vol. 18 No. 7, pp. 509-533.

Triguero, A., Moreno-Mondajar, L. and Davia, M.A. (2015), "Eco-innovation by small and medium-sized firms in Europe: from end-of-pipe to cleaner technologies", Innovation, Vol. 17 No. 1, pp. 24-40.

Urbinati, A., Chiaroni, D. and Chiesa, V. (2017), "Towards a new taxonomy of circular economy business models", Journal of Cleaner Production, Vol. 168 No. 1, pp. 487-498.

Verbeke, A. and Buysse, K. (2003), "Proactive environmental strategies: a stakeholder management perspective”, Strategic Management Journal, Vol. 24 No. 5, pp. 453-470. 
Wagner, M. (2007), "On the relationship between environmental management, environmental innovation and patenting: evidence from German manufacturing firms", Research Policy, Vol. 36 No. 10, pp. 1587-1602.

Walton, J. (2000), “Compulsory within voluntary environmental agreements?", Sustainable Development, Vol. 154 No. 3, pp. 146-154.

Wang, J.F. and Li, H.M. (2006), "The development of circular economy in China”, Aquatic Ecosystem Health and Management, Vol. 9 No. 1, pp. 99-103.

Wilmshurst, T.D. and Frost, G.R. (2001), "The role of accounting and the accountant in the environmental management system", Business Strategy and the Environment, Vol. 10 No. 3, pp. 135-147.

Witjes, S. and Lozano, R. (2016), "Towards a more circular economy: proposing a framework linking sustainable public procurement and sustainable business models", Resources, Conservation and Recycling, Vol. 112 No. 1, pp. 37-44.

Wu, Q., He, Q., Duan, Y. and O'Regan, N. (2012), “Implementing dynamic capabilities for corporate strategic change toward sustainability", Strategic Change, Vol. 21 Nos 5/6, pp. 231-247.

Yang, C., Cao, J., Zeng, H., Xiao, X., Zhang, K. and Li, Z. (2019), "Resource value flow analysis of papermaking enterprises: a Chinese case study", Journal of Cleaner Production, Vol. 213 No. 1, pp. 577-587.

Yuan, Z., Bi, J. and Moriguichi, Y. (2006), "The circular economy: a new development strategy in China", Journal of Industrial Ecology, Vol. 10 Nos 1/2, pp. 4-8.

Zamfir, A.-M., Mocanu, C. and Grigorescu, A. (2017), "Circular economy and decision models among European SMEs”, Sustainability, Vol. 9 No. 9, pp. 1507.

Zeng, H., Chen, X., Xiao, X. and Zhou, Z. (2017), "Institutional pressures, sustainable supply chain management, and circular economy capability: empirical evidence from Chinese eco-industrial park firms", Journal of Cleaner Production, Vol. 155 No. 1, pp. 54-65.

Zhang, J.A. and Walton, S. (2017), "Eco-innovation and business performance: the moderating effects of environmental orientation and resource commitment in green-oriented SMEs", $R \& D$ Management, Vol. 47 No. 5, pp. 26-39.

Zhijun, F. and Nailing, Y. (2007), "Putting a circular economy into practice in China", Sustainability Science, Vol. 2 No. 1, pp. 95-101.

Zhou, Z., Zhao, W., Chen, X. and Zeng, H. (2017), "MFCA extension from a circular economy perspective: model modifications and case study", Journal of Cleaner Production, Vol. 149 No. 1, pp. 110-125.

Zhu, Q., Cordeiro, J. and Sarkis, J. (2013), "Institutional pressures, dynamic capabilities and environmental management systems: investigating the ISO 9000 - environmental management system implementation linkage", Journal of Environmental Management, Vol. 114, pp. 232-242.

Zollo, M. and Winter, S.G. (2003), "Deliberate learning and the evolution of dynamic capabilities", Organization Science, Vol. 13 No. 3, pp. 339-351.

Zubeltzu-Jaka, E., Andicoechea-Arondo, L. and Alvarez Etxeberria, I. (2018), "Corporate social responsibility and corporate governance and corporate financial performance: bridging concepts for a more ethical business model”, Business Strategy and Development, Vol. 1 No. 3, pp. 214-222. 
SAMPJ

11,7

\section{8}

Figure A1.

Main questions of the survey

\section{Appendix}



ECO-DE SIGN AND ECO-INNOVAIION IN BUSNESSES

Read carefully the following questions and seloct one of the values, taling into account that "O" means that the measures described have NOT been ECO-NMONATION ECO-DESTCNAND CTRCUL.AR ECONOMY

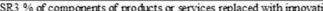

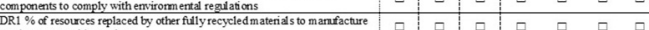
proacas or provide sentices (denaterialization) (multefuntion) CSE3 \% of products' design or services modfied to increase recyclablity
(waste prevention) RESOURCE EFFCIENCY ANDRENEWABLES

SR1 $\%$ of equipment or faclities replaced and or improved to reduce

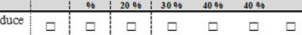
\begin{tabular}{l|l|l|l|l|l|l|l}
\hline $\mathrm{SR} 3 \%$ of processes and operating procedures replaced or improved to & $\square$ & $\square$ & $\square$ & $\square$ & $\square$
\end{tabular}

TTRODUCTION N FIRUS



Please, specify tha percentage and piace of the following waste and activites and their relerance for a CE:

CW1 Place of recycling waste (reated to be recyded 2 \% \%ithin the conpany. CW2 Place of recovering waste and reuse $\quad \%$ within the comp any.

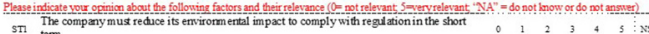

Corresponding author

Sabina Scarpellini can be contacted at: sabina@unizar.es

For instructions on how to order reprints of this article, please visit our website: www.emeraldgrouppublishing.com/licensing/reprints.htm

Or contact us for further details: permissions@emeraldinsight.com 